\title{
Hypercompetition: A Review and Agenda for Future Research
}

\author{
Lindskov, Annesofie
}

Published in:

Competitiveness Review

DOI:

10.1108/CR-06-2021-0097

Publication date:

2022

Document Version

Peer reviewed version

Citation for published version (APA):

Lindskov, A. (2022). Hypercompetition: A Review and Agenda for Future Research. Competitiveness Review, 32(3), 391-427. https://doi.org/10.1108/CR-06-2021-0097

\section{General rights}

Copyright and moral rights for the publications made accessible in the public portal are retained by the authors and/or other copyright owners and it is a condition of accessing publications that users recognise and abide by the legal requirements associated with these rights.

- Users may download and print one copy of any publication from the public portal for the purpose of private study or research.

- You may not further distribute the material or use it for any profit-making activity or commercial gain.

- You may freely distribute the URL identifying the publication in the public portal.

Take down policy

If you believe that this document breaches copyright please contact rucforsk@kb.dk providing details, and we will remove access to the work immediately and investigate your claim. 


\section{Emerald Competitiveness Review}

\section{HYPERCOMPETITION: A REVIEW AND AGENDA FOR FUTURE RESEARCH}

\begin{tabular}{|r|l|}
\hline Journal: & Competitiveness Review \\
\hline Manuscript ID & CR-06-2021-0097.R2 \\
\hline Manuscript Type: & Conceptual Research Paper \\
\hline Keywords: & $\begin{array}{l}\text { hypercompetition, temporary competitive advantage, disequilibrium, } \\
\text { competitive aggressiveness }\end{array}$ \\
\hline \multicolumn{2}{|l}{} \\
\hline
\end{tabular}

\section{SCHOLARONE \\ Manuscripts}




\title{
HYPERCOMPETITION: A REVIEW AND AGENDA FOR FUTURE RESEARCH
}

\author{
ABSTRACT \\ Purpose: The aim of the study is to review and understand the dimensionality of hypercompetition, \\ factors causing a hypercompetitive environment, and the consequences of hypercompetition on \\ markets. Thereby, the purpose of the study is to cover the main contributors in the research field of \\ hypercompetition and explore their findings and different views on hypercompetition. \\ Design/methodology/approach: Systematically review 131 conceptual and empirical studies published \\ or presented at a conference in the last 25 years, with the focus on the definitions, causes, and \\ consequences (or presumed effects) of hypercompetition. In the paper, I follow the well-known SLR \\ method by Tranfield et al. (2003).
}

Findings: The contribution of the study is to advance the knowledge of researchers and managers, in such way that it becomes easier for them to select relevant variables to measure hypercompetition and identify strategies for gaining temporary competitive advantages in hypercompetitive environments. The construct of hypercompetition required a consolidation of commonalities in the definitions and characteristics used by scholars, to ensure that proper assumptions and variables are being used to measure hypercompetition in future research. Several ways to measure the effects of hypercompetition on firms, industries and individuals have been proposed, but the field still lacks of a clear definition on how to directly measure the construct.

Practical implications: In this paper, I highlight three managerial implications of hypercompetition: (1) action-based strategy, (2) the determinants of hypercompetition, and (3) the importance for managers of accurately establishing their firm's competitive situation. 
Originality: Previous reviews in the area have either focused on specific components or effects of hypercompetition. The present study collectively takes into consideration the definitions, causes, and consequences of hypercompetition on firms, industries and individuals. The contribution of the paper is to indicate future opportunities and challenges within research on hypercompetition.

Keywords: hypercompetition, temporary competitive advantage, disequilibrium, competitive aggressivenes 


\section{INTRODUCTION}

Approximately three decades ago, D'Aveni (1994) argued that a new revolution of competitive strategies was brewing, as managers and strategy researchers were discovering that the existing models of strategy were nearly obsolete in a new fast-paced competition. D'Aveni (1994) defines the new type of competition as "hypercompetition", and describes it as an environment of "intense change, in which flexible, aggressive, innovative competitors move into markets easily and rapidly, eroding the advantages of the large and established player" (D'Aveni, 1994: p. 6), where no competitive advantage is sustainable. The hypercompetition thesis has led to a steady stream of studies of this form of competition, and inspired a related stream of literature on temporary competitive advantage (Dagnino et al., 2020). While some have pointed to hypercompetition as the "new normal" (Thomas, 1996; Thomas and D'Aveni, 2009; Wiggins and Ruefli, 2005), others have questioned its very existence (Castrogiovanni, 2002; Lindskov et al., 2020; McNamara et al., 2003; Vaaler and McNamara, 2010). This review surveys a quarter century of literature on hypercompetition and provides a comprehensive overview of the causes and effects of hypercompetition, of the ways it has been measured, and of what gaps remain to be explored.

Over the years, the theory of hypercompetition has attracted increasing attention within management literature, generating different streams of research on hypercompetition. The majority of these studies investigate the effects of hypercompetition at different levels of analysis, whereas others focus more on how to respond to such intense and volatile environmental conditions. Along with these studies, scholars have provided a variety of views and understandings, generating several definitions and characteristics of a hypercompetitive environment. Despite the interest from management scholars, the literature has provided a mixed bag of theoretical and methodological issues, such as the 
inconsistency in the empirical findings related to the existence (Thomas, 1996; Thomas and D'Aveni, 2009; Wiggins and Ruefli, 2005) or nonexistence (Castrogiovanni, 2002; Lindskov et al., 2020; McNamara, Vaaler and Devers, 2003; Vaaler and McNamara, 2010) of hypercompetition. This leaves several questions unanswered for future research to explore.

Since the 1990s, several literature reviews on hypercompetition have been published or presented at a conference (Dagnino et al., 2020; Saadatmand et al., 2018; Turgay and Emeagwali, 2012). Most recently, the study by Dagnino et al. (2020) reviews temporary competitive advantages. Although, Dagnino et al. (2020) highlights a dimension of hypercompetition, they do not explicitly review the phenomenon of hypercompetition. In sum, while the hypercompetition research field is expanding quite quickly, scholars have not yet had access to a review that is both comprehensive, analytical, and forward-looking. Therefore, a systematic review of hypercompetition literature is increasingly important for several reasons: (1) a timely synthesis of the literature will contribute to the basis of theory building in the area of hypercompetition; (2) an identification of the components of hypercompetition may help scholars in selecting variables for measuring whether markets have become hypercompetitive; and (3) the causes and effects identified and the research framework proposed in this study can be adopted and further developed by future studies.

This review is based on 131 empirical and theoretical studies following the systematic literature review approach proposed by Tranfield et al. (2003). I systematically gather, analyse and synthesise hypercompetition contributions to the management literature in a way that facilitates further research and supports management practice. First, a brief review of the development of the research on hypercompetition in order to identify the issues that remain to be resolved. Second, the growing literature on this topic has provided several definitions and characteristics of the construct. Such 
proliferation of the definitions of hypercompetition shows the dynamism generated on the topic from different research fields and disciplines, but it also produces confusion and may hinder effective progress within this research area. Therefore, this construct requires a consolidation of commonalities in the definitions and characteristics used by scholars, to ensure that proper assumptions and variables are being used in future research. Third, the rapid growth of the literature on hypercompetition, and the diversity in the causes and effects of such an environment, have led to a body of research pointing in different directions. For instance, scholars argue that hypercompetition affects different variables at both the industry-, firm-, individual-, and team-level. Accordingly, the literature needs a review and clarifications of the causes and effects of hypercompetition for guidance for future research. This review offers a revised framework of hypercompetition, creating a structure of its causes, dimensions, and presumed effects.

\section{REVIEW APPROACH}

In this study, I employ a systematic literature review (SLR) approach following studies such as Kraus et al. (2020) and Transfield et al. (2003). Thus, an approach that follows three main steps (1) planning, (2) conducting, and (3) reporting and dissemination. This approach differs from the traditional and narrative literature review by being more systematic and explicit in the selection of literature. The goal is to identify a representative sample of literature on the causes, dimensions and presumed consequences of hypercompetition. This method involved several choices, which are outlined below, and shown in Figure 1:

Figure 1 about here 
In the first step, I identified the need for an SLR on the topic, explained the motivation, and developed a review protocol. In the second step, I first made a broad search in two widely used academic databases Scopus and Web of Science (WoS) for literature explicitly using the term "hypercompetition" in the title, abstract, or keywords. This was to ensure that the review had a wide spectrum of potentially relevant literature. In order to account for terminological heterogeneity in the literature, the search was expanded to "hypercompetitive" and "hypercompetitiveness" with and without a hyphen. I relied on these terms to limit the search to studies explicitly addressing hypercompetition and using the terms in their title, abstract or keywords. Rather than providing an overview and synthesis of studies of related concepts. Thus, this search returned 1,095 results. Then, to ensure that the search was not too broad and still focused on a relevant set of research fields, I limited the categories to "business" and "management". The search was also restricted to the document types: “articles", "proceeding paper", "review”, “editorial material” and “early access". This resulted in 160 records from the WoS and 220 records from Scopus written in English. After removing duplicates, 275 records were left for title and abstract analysis. Then, I thoroughly screened the titles and abstracts of the 275 articles to determine whether each article explicitly reported the causes, dimensions or presumed effects of hypercompetition, which resulted in exclusion of 144 articles from further analysis. Specifically, I excluded articles that mentioned the term "hypercompetition" (often in the abstract), but failed to explain or use the concept (e.g. using the term only as a theoretical hook). I thus identified 131 articles, which form the basis of this SLR. In the Appendix, Table 1A lists the articles included in the review. 
In the third and final step, I synthesised the studies by first running an analysis using a simple set of categories (e.g. journal title, year of publication, findings), and then a thematic analysis of the field using three categories (1) definitions, (2) causes, (3) effects of hypercompetition.

\section{RESEARCH ON HYPERCOMPETITION: EMERGENCE OF THE FIELD}

Over the years, scholars have argued that strong exogenous forces (e.g. the globalisation and technological revolution) have changed and reshaped the competitive landscape worldwide (e.g. D’Aveni, 1994; Lahiri et al., 2008). As a result of these exogenous changes, the environmental conditions are becoming more uncertain, dynamic and complex. The well-known stable equilibrium that defined competition in the $20^{\text {th }}$ century is being rapidly transformed into a constant state of disequilibrium (i.e. hypercompetition) (D’Aveni, 1994).

Although, the roots of the concept of hypercompetition go far back to the traditional theories of competition (i.e. neoclassic economy, industrial economy and industrial organisation), D’Aveni (1994) stresses a more dynamic view. D’Aveni (1994) argues that strategic concepts such as "sustainable advantage, barriers to entry, long-range planning, the use of financial goals to control strategy implementation, and SWOT analysis" (D’Aveni, 1994: p. 12) all fall apart when we start to consider the dynamics of competition. D'Aveni (1994) continues "stable equilibria are impossible because constantly shifting technology, global competitors, and strategic positioning will result in frequent or almost constant disequilibrium in which new entrants and established competitors disrupt the balance of power and gain temporary superiority" (D’Aveni, 1994: p. 18). The more traditional approaches to strategy focus on the creation of competitive advantage, while D'Aveni (1994) takes an alternative view and argues that strategies should also incorporate the creative destruction of competitors' advantages. This draws a link back to Schumpeter (1934, 1939), who viewed superior economic 
performance as achievable through "successful innovation in capitalist society and is temporary by nature" (Schumpeter, 1939: p. 105). In this theory, Schumpeter $(1934,1939)$ argues that firms can, through innovation, gain superior economic performance, depending on the pattern of creative accumulation and creative destruction (Baaij et al., 2004; Breschi et al., 2000). Similarly, D'Aveni (1994) suggests that firms make a series of temporary advantages through, for example, product innovations or technological advancements. However, these advantages last only until competitors have either duplicated or outmanoeuvred them. Therefore, firms must constantly develop new initiatives. In the traditional and stable equilibrium, competitive advantage is also eroded, but over longer time, resulting in a longer product life cycle (D'Aveni, 1994). Thus, in a hypercompetitive market these cycles are more compressed, and therefore sustaining advantage has become increasingly difficult.

Strategy scholars have typically assumed that sustainable competitive advantages exists (e.g. Baaij et al., 2004; Penrose, 1959; Porter, 1980, 1985). Considerable effort has been dedicated to empirically demonstrate the existence of superior economic performance and sustainable advantages. However, around the 1990s scholars started to question whether competitive advantages were sustainable (Ilinitch et al., 1996). Scholars proposed 'early warning signals' of dynamic environments with similar characteristics to hypercompetition, such as "hyperturbulence" and "high-velocity" environments (Eisenhardt and Bourgeois, 1988; Zohar and Morgan, 1996). Although some previous references to the concept of hypercompetition may be found in the literature, it is after the publication of D'Aveni's (1994) seminal book that the construct generated an increasing flow of studies on the phenomenon, as shown in Figure 2.

Figure 2 about here 
Early contributions came from the special issue in Organization Science, where the editors challenged management scholars to answer the question, "where are the theories for the 'new' organisational forms?" (Ilinitch et al., 1996: p. 211). In this issue, scholars seem to agree that the nature of competition has shifted towards an environment with increasing rivalry, affecting the sustainability of profit levels (e.g. Thomas, 1996; Young et al., 1996). Collectively, these articles provided with different models, frameworks, methods, strategies, and organisational structures addressing the difference between hypercompetition and the traditional type of competition. The issue increased interest among strategy scholars and created a debate as to whether industries are becoming hypercompetitive and advantages less sustainable. Some scholars provided empirical evidence of a shift in the nature of competition towards hypercompetition (e.g. Thomas and D'Aveni, 2009), whereas others found no evidence of a decrease in profit levels (e.g. McNamara et al., 2003) or intra-industry differences in the level of competition (Lindskov et al., 2020; Vaaler and McNamara, 2010).

Later on, Strategic Management Journal published a special issue in 2010, focusing on the antecedents, consequences and management of temporary competitive advantages. In this issue, scholars provided a variety of studies on the competitive actions of firms. Some measured the links between competitive advantage and rivalry, whereas others investigated the possible effects of hypercompetition on a firm's resources and capabilities (e.g. Hermelo and Vassolo, 2010; Lee et al. , 2010; Sirmon et al., 2010). Since then, the research on hypercompetition has provided a large array of both conceptual, theoretical and empirical studies. As depicted in Figure 2, the studies on hypercompetition have developed from focusing on competitive advantage, economic growth and 
competitive strategy to now investigating dynamic capabilities and technological innovations in hypercompetitive environments.

Research on hypercompetition has explored a wide array of empirical contexts ranging from technology-intensive, manufacturing, automobile, hotel industry, and hairstyling industries (e.g. Alcalde-Giraudo et al., 2020; Hoisl et al., 2017; Lee et al., 2010; Mattila, 2001; Thomas and D'Aveni, 2009; Vaaler and McNamara, 2010). Technology-intensive industries are often mentioned as a canonical example of a hypercompetitive market (e.g. Lee et al., 2010; McNamara et al., 2003; Thomas and D'Aveni, 2009), but it is not the most empirically studied industry. A sector that has been examined intensively and empirically by scholars is the manufacturing sector (e.g. McNamara et al., 2003; Thomas, 1996; Thomas and D'Aveni, 2009). Notably, the majority of the studies on hypercompetition use the context of the United States. Only a few of the studies have provided other contexts such as Denmark, Norway, and Latin America (Hanssen-Bauer and Snow, 1996; Hermelo and Vassolo, 2010; Lindskov et al., 2020). In general, the theory of hypercompetition does not specify how to determine whether a firm is operating in a hypercompetitive market. Therefore, scholars use different methodologies to measure different variables to explain hypercompetition. In turn, the lack of construct clarity makes operationalisation and measurement difficult. Additionally, the hypercompetition literature does not possess a clear research model laying out the variables causing and driving hypercompetition, and affecting industry environments. These different characteristics and lack of clarity may have hindered the cumulativeness of research effort to investigate the phenomenon of hypercompetition.

\section{HYPERCOMPETITION: DEFINITION AND SCOPE}


Since the seminal work of D'Aveni (1994), a lot has been said about the phenomenon. Scholars have focused on different components or dimensions in their definition of hypercompetition, such as market instability (e.g. Castrogiovanni, 2002; McNamara et al., 2003), disequilibrium (e.g. D’Aveni, 1999; Volberda, 1996), the frequency of competitive attacks (Hermelo and Vassolo, 2010) and temporary competitive advantages (e.g. Bogner and Barr, 2000; Harvey et al., 2000). Although definitions differ across studies, as shown in Table A2 in the Appendix, the majority of them are close to or consistent with D'Aveni's (1994) definition of hypercompetition. Altogether, the definitions points to several dimensions of a hypercompetitive environment that highlight the major theoretical underpinnings (competitive advantage, the state of equilibrium and rivalry). The main definitions are shown in Table 1 (if you are interested in all of the definitions of the concept see Appendix A2).

Table 1 about here

Temporary advantage. The most frequently identified dimension is temporary competitive advantage (for a recent review of the literature on temporary advantages see Dagnino et al. (2020)). In the theory of hypercompetition, D’Aveni (1994) questions the well-known view of sustainable competitive advantages and argues that “today's strengths become tomorrow's weaknesses so quickly that sustaining advantages is nearly impossible" (1994: p. 6), as the environment constantly changes. D’Aveni (1994) continues: "No organisation can build a competitive advantage that is sustainable" (D’Aveni, 1994: p. 6), as every advantage will be eroded by competitors over time. This means a firm performing poorly today, may be the star of the industry tomorrow, and a leading firm may erode its market share if it fails to keep moving forward. The 'old' advantage is no guarantee of future success, not even for the largest and most successful firm (D’Aveni, 1994; Harvey et al., 2000; Liao et al., 2009). The solution scholars have provided to this problem is that firms need to disrupt their status quo 
and stay one step ahead of the competition by creating a series of temporary advantages, rather than relying on an advantage (D’Aveni, 1994; Dagnino et al., 2020; Liao et al., 2009; Veliyath and Fitzgerald, 2000). This means firms need to design and implement a series of, for example, product innovations (Volberda, 1996), dynamic capabilities (Liao et al., 2009; Volberda, 1996) or process innovations (Ali et al., 2020; D’Aveni, 1994; Harvey and Novicevic, 2001; Lahiri et al., 2008; Richardson, 1996). Scholars measure these temporary advantages by using a function of time or "the pace of erosion, or regression to the mean, of abnormal returns" (Pacheco-De-Almeida, 2010: p. 1502). However, the empirical evidence of decreasing sustainability in competitive advantages over time are mixed (Lindskov et al., 2020; McNamara et al., 2003; Vaaler and McNamara, 2010; Wiggins and Ruefli, 2005).

Disequilibrium. The state of equilibrium in this new hypercompetition is said by scholars to differ from the traditional and stable equilibria (D'Aveni, 1999; Palmer et al.,, 2001), but not saying that the environment is something really 'new' (Fiegenbaum et al., 2001; Parayre and Hurry, 2001). Scholars link the equilibrium to different economic theories. Some argue that the conditions are similar to what Schumpeter (1934, 1939) defines as ‘creative destructions' (Craig, 1996; D’Aveni, 1994), whereas others argue that the environment should be seen as a complex combination of perfect competition and oligopoly (e.g. Fiegenbaum et al., 2001). However, scholars seem to agree that the environment includes a high level of turbulence and frequent competence-destroying changes, creating a state of disequilibrium (e.g. D’Aveni, 1999; D’Aveni et al., 2010; Fiegenbaum et al., 2001). This means the 'hyper'-market's capacity to meet demand is limited, as it constantly changes, making it unbalanced (Burke and van Stel, 2014), which can be reflected in aspects such as volatility in business 
performance, rapidly changing customer preferences and constantly eroded market share (e.g. Chen et al., 2010; D'Aveni et al., 2010; Parayre and Hurry, 2001).

Aggressive Competitors. In hypercompetitive markets, the movement of competitors is rapid, intense, unexpected, and unconventional, where their aim is to constantly develop advantages and erode rivals (D’Aveni, 1994; Hoisl et al., 2017; Ruiz et al., 2017). Consistent with the industrial organisation literature, the theory of hypercompetition suggests that rivalry should be framed as the sequence of moves from competitors within the industry (Young et al., 1996). This means when competitors act highly aggressively (i.e. high number of competitive actions), the rivalry within the industry is high. As shown by Young et al. (1996), increasing rivalry affects firm performance negatively. More specifically, in 'hyper'-markets, firms are not independent but affected by their competitors' actions and are prone to react or they may not survive.

\section{HYPERCOMPETITION: CAUSES AND CONSEQUENCES}

Several strong exogenous forces have been cited as contributing causes of hypercompetition. This includes forces such as technological innovations, globalisation, aggressive competitors, institutional changes, deregulations, hedge funds, the rise of China and other emerging regions, demographical trends and economic changes, but what are the main changes contributing to a hypercompetitive environment (e.g. D'Aveni, 1994; D’Aveni et al., 2010; Hermelo and Vassolo, 2010; Ilinitch et al., 1996; Lindskov et al., 2020)? Similarly, scholars have mentioned a variety of consequences (or presumed effects) at both the industry-, firm-, and individual- and team-level. These causes and consequences are illustrated in Figure 3. The components of hypercompetition discussed in the previous section are equally found in the figure. 
Figure 3 about here

\subsection{Causes of Hypercompetition}

Early contributions to the hypercompetition field assume that the causes of hypercompetition are new customer preferences, technological innovations and globalisation (D’Aveni, 1994). Since then, these causes have been extended. Now, scholars add the demographical and social trends, economic changes, and institutional changes to the list of causes contributing to a hypercompetitive environment (Castrogiovanni, 2002; Lahiri et al., 2008; McNamara et al., 2003). To guide future research, this section reviews the past research describing the causes of hypercompetition. This analysis can be viewed in Table 2 .

Table 2 about here

Globalisation. As world trade increases, technology and knowledge transfer becomes quicker and the level of competition and dynamism increases (e.g. Hanssen-Bauer and Snow, 1996; Uhl-Bien et al., 2007). Over time, globalisation has affected the economy, business environment and society in different ways such as reducing entry barriers. Now, firms can more easily penetrate new markets and relocate their production activities abroad (e.g. Akhter, 2003; Bayraktar and Ndubisi, 2014; Chen et al., 2010; Schneider, 2002). Hypercompetition is said to be the corollary of the globalisation process (Hanssen-Bauer and Snow, 1996; Lahiri et al., 2008; Veliyath and Fitzgerald, 2000; Walumbwa et al., 2014), as it increases corporate mobility between regions, reduces the importance of localisation advantages, and eliminates a potential source of sustainable competitive advantage. The globalisation process represents a cause of hypercompetition, because it opens up the market (i.e. increases rivalry) 
and competitive actions within an industry. Therefore, as globalisation proceeds, so too will hypercompetition.

Technological (r)evolution. One of the most striking manifestations of a hypercompetitive environment is the rapid and ongoing development of technological innovations by both entrepreneurial and incumbent firms to exploit new business opportunities (Christensen and Knudsen, 2008). This accelerating pace of technological innovations may force some firms to disrupt their current business model or invest more in R\&D. For example, the development of the internet created a new market for business and increased the level of competition within not only the broad technology sector, but also in other sectors (i.e. the suppliers market). This created an opportunity for firms to allow orders from abroad through online channels. As a result of the rapid development of new technologies, the technology life cycle has become shorter and competitors faster, thereby increasing the pace of product innovations and competitive attacks (Andrevski and Ferrier, 2019; Drejer, 2002).

Demographic and socio-economic changes. The economic up- and down-streams such as the global financial crisis, rising income levels, economic prosperity and the recent COVID-19 outbreak have affected the markets and competition worldwide, in some cases pushing industries towards a state of disequilibrium (e.g. Fourné et al., 2014; Hermelo and Vassolo, 2010; Lindskov et al., 2020; Ruiz et al., 2017). Globalisation has made markets across regions more influential on each other, therefore the economic growth in one industry may also generate growth in another industry (e.g. the supplier industry) (Chattopadhyay and Bhawsar, 2017; Nath and Newell, 1998).

Similar to economic changes, demographic and social trends also affect the competitive environment. Consider, for instance, the behavioural changes between generations. A new generation's taste in products or services may distinguish it from the older generation, enhancing an opening up of a 
new market (Ilinitch et al., 1996). This was the case for the Japanese beer industry that started to emerge in the 1980s, as the new generation had a different taste for beers (Craig, 1996). This change forced firms to produce new types of beer, and opened up the market for foreign competitors and intensified firm rivalry.

Institutional context and regulations. The different institutional environments (i.e. regulations, capital markets and governance) of regions may help explain the variations in the level of competition between regions (Ruiz et al., 2017; Schneider, 2002). As Hermelo and Vassolo (2010: p. 1457) argue "a diverse institutional context will generate different competitive conditions and also create dissimilar pressures on firms' competitive advantages", indicating that institutional changes may affect industries differently, depending on the region's development (i.e. developed and developing regions). In general, institutional changes can have various effects on the competitive environment. Consider, for example, lower transaction costs, which may decrease entry barriers, enhance competitive movements and decrease the ability to gain long-term superior economic performance, whereas enhanced intellectual property rights may encourage local investment in technology and favour knowledge and technology transfers from foreign firms to local firms (Chattopadhyay and Bhawsar, 2017; Drejer, 2002; Hermelo and Vassolo, 2010; Ruiz et al., 2017). Therefore, institutional changes can push industries towards a state of hypercompetition. This was the case in the financial sector in Thailand, where regional deregulation and liberalisation supported the marketing and sales activities within the sector, but also increased the level of competition and frequency of competitive attacks, resulting in decreasing sustainability of advantages (Ngamkroeckjoti and Johri, 2003).

Customer preferences. After globalisation, customers have become more sophisticated and demanding. They have more choice, which affects their general purchase behaviour, changing their bargaining 
power and bringing competitive pressure to a higher level (Akhter, 2003). Today, customers can use technologies to compare prices and quality of products, which may affect brand loyalty. Consequently, customers can easily switch from one provider to another when unsatisfied with the product, service or even delivery. In turn, that may drive customers to expect a higher quality, better service and faster delivery at a cheaper price (Akhter, 2003; Bayraktar and Ndubisi, 2014; Lahiri et al., 2008; McNamara et al., 2003; Thomas, 1996). This relatively high demand uncertainty makes it difficult for firms to gain superior economic performance over time and puts pressure on the competition between firms.

In the research on hypercompetition, scholars propose different factors causing hypercompetition. Considering all the factors, the underlying cause of hypercompetition is the actions of stakeholders. Without the actions of stakeholders, hypercompetition would not be present.

\subsection{Consequences of Hypercompetition}

The rich and growing literature on hypercompetition shows several implications stemming from the intense environment. Some of these studies show that hypercompetition affects both industries (e.g. dynamism, munificence and complexity), firms (e.g. firm performance, mortality, and business models), and individuals and teams (e.g. decision-making and cognitive framework). The following sections describe the effects and implications corresponding to hypercompetition. The analysis of the presumed effects can be viewed in Table 3.

Table 3 about here

\subsubsection{Industry-level}


Scholars argue that the environmental tendencies of a hypercompetitive market affects industry structure, such as increasing dynamism, decreasing munificence and increasing industry complexity.

Munificence. As the barriers to entry start to decline industry density and rivalry increases, leading to decreasing munificence. That means the environmental capacity tends to be exploited and resources become scarce (Castrogiovanni, 2002; Lindskov et al., 2020; McNamara et al., 2003; Vaaler and McNamara, 2010). In hypercompetitive environments, firms will exploit the available resources until the resource usage of the population reaches its environmental capacity limit. Consequently, industry munificence starts to decline as the capacity approaches its limit. If an industry only has a few unexploited resources available, it becomes difficult for firms to identify and utilise those resources, thus decreasing the ability to support population growth (Castrogiovanni, 2002; Lindskov et al., 2020; McNamara et al., 2003; Vaaler and McNamara, 2010). Then, firms start to "struggle" for their existence in these 'hyper'-markets, creating a competitive pressure.

Dynamism. The markets are becoming unstable, due to short product life cycles, new technological innovations, frequent entries by unexpected firms, repositioned incumbent firms, and radical changes to the market boundaries such as diverse industries that starts merging. In other words, in hypercompetitive industries the level of uncertainty, dynamism, heterogeneity among industry members and hostility are increasing (Aupperle, 1996; D’Aveni, 1994). Competition has shifted towards an arena where timing and know-how are important for eroding an advantage (Richardson, 1996). The rate of change and innovation within hypercompetitive markets, as well as the level of uncertainty and unpredictability of competitors' actions and customers' demands are increasing industry dynamism. This dynamism may be reflected in the frequency of changes in products, 
processes and organisational structures (Castrogiovanni, 2002; Dess and Beard, 1984; Lindskov et al., 2020; McNamara et al., 2003; Vaaler and McNamara, 2010).

Complexity. Firms may use different strategies in their pursuit of growth and competitive advantage, which may lead to greater heterogeneity among industry members (Castrogiovanni, 2002; Thomas, 1996; Thomas and D'Aveni, 2009). This industry heterogeneity may increase industry complexity. This can be reflected in many ways such as the variety of products, services, distribution channels, and stakeholders within an industry. However, the heterogeneity may differ from industry to industry, as the need for processes, products and services may vary. For instance, a bakery producing bread is less complex than an IT firm that designs and manufactures microchips. However, scholars argue that hypercompetitive industries in general have a high level of complexity that may require specific structures, processes and infrastructures (D'Aveni, 1999; D'Aveni et al., 2010).

\subsubsection{Firm-level}

Over the years, several scholars (e.g. Bettis and Hitt, 1995; D'Aveni, 1994) have argued that the competitive environment is evolving and becoming hypercompetitive, requiring rapid product innovations, new business models, new strategic alliances, and more aggressive behaviour in a firm's pursuit of growth and survival.

Business performance. The conditions in a hypercompetitive market make it difficult for firms to gain and sustain competitive advantages. Consequently, long-run firm performance is declining, and as D'Aveni (1994: p. 46) argues only "short periods of profits are achievable". The hypercompetition literature shows evidence of an increase of volatility in firm performance (Thomas, 1996; Thomas and D’Aveni, 2009), possibly caused by the constant attacks and counterattacks. Similarly, scholars have found that hypercompetition decreases the duration of sustainable competitive advantages, and business 
performance is becoming less persistent over time (D’Aveni, 1994; Thomas, 1996; Thomas and D’Aveni, 2009; Wiggins and Ruefli, 2005). This may occur because firms are constantly eroding advantages from each other, making them impotent to every competitive movement, as they just generate a new series of counterattacks.

Market Share. As industry density increases, firms start battling others for market share (Makadok, 1998; Parayre and Hurry, 2001; Vaaler and McNamara, 2010). Scholars have found some advantages and disadvantages associated with the leading or non-leading market share positioning in 'hyper'markets. Makadok (1998) found that first-movers and early-entry-movers often have a pricing advantage, as their product price tends to be higher and more sustainable than later entrants. Ferrier et al. (1999) argue that firms with the greatest market share often experience market share erosion and dethronement of their leading position. While Nault and Vandenbosch (1996) contribute with a different perspective, arguing that leading firms may sometimes be forced to cannibalise their own advantages, by launching a new series of temporary advantages to secure their future market position. Overall, the market share of firms in hypercompetitive markets is constantly changing.

Business mortality. The sustainability of any given competitive advantage is dependent on the threats of the competitors' ability to innovate or imitate (Pacheco-De-Almeida, 2010). The low barriers to entry, high level of imitation and increasing product innovations in 'hyper'-markets are forcing firms to adapt to these new and intense environmental conditions. Some incumbent firms may have accumulated rules and stagnated their relationship with customers, which may render them less agile and re-structuring increasingly expensive. On the other hand, new entrants may be more flexible towards change, but not having the right resources and capabilities to support a re-configuration (García-Sánchez et al., 2014; Vassolo et al., 2017). Furthermore, the new entrants may also be less 
experienced, thus more susceptible to market shocks. Consequently, competitive pressure is pushing firms (both new entrants and incumbent firms) to make organisational changes that may raise the risk of failure and business mortality (i.e. decreasing firm survival) (Lindskov et al., 2020; McNamara et al., 2003; Vaaler and McNamara, 2010).

Competitive actions. The phenomenon of temporary advantage is demanding that firms compete aggressively, if they want to survive and thrive in a hypercompetitive market (Andrevski and Ferrier, 2019; Chen et al., 2010). Firms can compete aggressively through product innovations, price cuts and marketing campaigns, and thereby gaining temporary superior economic performance. However, they must have the needed resources and capabilities to increase the speed and development of the competitive actions while lowering cost (Andrevski and Ferrier, 2019). Competing aggressively is necessary for some firms, but not sufficient for all firms (Andrevski and Ferrier, 2019; Chen et al., 2010). For example, while competing aggressively may work for firms with specialised resources, it may not be efficient for firms with broad resources. Therefore, firms need to understand how fast and aggressive they have to be in their competitive actions.

Organisational structure. As Sirmon et al. (2010) argue, competitive advantage is not only built through a firm's strengths (e.g. resources and capabilities) alone, but the weaknesses do also have a direct impact on the relative performance. In hypercompetitive markets, firms are frequently under attack by competitors, which forces them to find new sources of revenue. For some firms, this may require them to restructure their organisation. Scholars argue that firms need to either combine the traditional and new practices (Palmer et al., 2001), or replace the traditional practices with new practices (Galunic and Eisenhardt, 1996). In general, firms could make several changes to the organisational structure such as create new strategic alliances (e.g. Hanssen-Bauer and Snow, 1996), 
build new business models (e.g. Chattopadhyay and Bhawsar, 2017), penetrate new markets (e.g. Atesci et al., 2010), globalise (e.g. Kaivo-oja and Lauraeus, 2018) or add new resources and capabilities (e.g. Veliyath and Fitzgerald, 2000; Waard et al., 2012) to prepare themselves for future competitive attacks or challenges.

Product life cycle. The rapid technological revolution has put pressure on the life cycle of both technology and products. As Richardson (1996: p. 200) argues, firms can no longer depend on " a few designs from the most savvy designers", they should try out many, quickly imitate others, and only supply with the demanded products. Therefore, firms need to increase the speed of product development (i.e. from idea to product), as the life cycles of both product and technology are becoming shorter and shorter over time (Harvey et al., 2000; Pacheco-De-Almeida, 2010). Some scholars even argue that the life cycles in disruptive environments never reach maturity (D'Aveni et al., 2010). D’Aveni et al. (2010) argue that firms have to "self-reproduce, cannibalise, innovate, and self perpetuate by incessantly innovating, reviving, and reinitiating the initial stages of different waves of industry and product life cycles" (p. 1372) to survive in a hypercompetitive environment. As a side effect of continuous product innovation, firms may over time become exhausted or blinded by their 'temporary' success and forget to make the new and required changes (D'Aveni et al., 2010; PachecoDe-Almeida, 2010), which may result in eroded advantages, declining business performance, or at worst business mortality.

\subsubsection{Individual or Team-level}

Conventionally, the resource-based view posits that the resources and capabilities within a firm are key to superior economic performance (i.e. enable the firm to gain and sustain competitive advantage) (Barney, 1991; Foss and Knudsen, 2003; Peteraf, 1993). Given the increasing amount of 
imitation and innovation within hypercompetitive industries (Pacheco-De-Almeida, 2010), scholars have provided other theoretical perspectives complementing the RBV by focusing on how firms can gain temporary advantages through resources and capabilities. The rapidly changing hypercompetitive environment is putting pressure on the capabilities of firms in making fast and good strategic decisions with less reflection time (Walumbwa et al., 2014). In this review, some studies have focused on the need for decision-making teams, whereas others take a broader view on management capabilities.

First, scholars argue that the management capabilities of firms in hypercompetitive markets are very important, as the choices of managers may create competitive advantages or, conversely, decrease firm performance. In general, managers have to respond urgently to new attacks from competitors as well as to rather predictable changes (Waard et al., 2012; Walumbwa et al., 2014). The intensive competition in 'hyper'-markets requires managers to be both transcendent (i.e. go beyond the expected) and flexible in their leadership (Christensen and Knudsen, 2008; Gallo and Gardiner, 2007; Karuppan and Kepes, 2006; Volberda, 1996).

Second, scholars argue that a firm's sensory and analytical skills are critical for good decisionmaking. In hypercompetitive markets, the increasing time constraint and information overload are making it difficult for managers to find the most reliable information to base their decisions on. The cognitive framework that managers have used to make sense of and react within a stable equilibrium are significantly compromised in hypercompetitive markets (Lahiri et al., 2008). From the existing literature, there is no doubt that firms need now, more than ever, the right management 'sensing' or analytical capabilities, as they constantly have to identify new business opportunities and build new competitive advantages (Bayraktar and Ndubisi, 2014; D’Aveni, 1999, 1994; Waard et al., 2012). This refers to their capabilities to (1) distinguish between potential threats and opportunities from the variety 
of changes in the surrounding environment, (2) interpret these changes (i.e. how the manager assigns meaning to the stimuli), and (3) acquire, integrate and exploit new information and existing knowledge (Waard et al., 2012). In sum, managers need to know how to recognise, filter and apply information quickly in order to provide with both effective directions for the employees and for the firm in general.

Third, Chen et al. (2010) argues that top management teams are necessary for overcoming the extensive volatility in hypercompetitive market, as it is through the firm's actions and aggressiveness that the firm gains competitive advantage and performance. These teams may benefit from being dynamic and cohesive (Chen et al., 2010), but should not be too diverse. Scholars argue that team diversity and job-related capabilities may increase the likelihood that the team will observe more environmental threats, opportunities and general tendencies, than one individual manager (Bogner and Barr, 2000; Hoisl et al., 2017). However, firms have to think carefully about this team composition, as these individuals may be from various parts of the organisation bringing in different perspectives based on their functional orientation (Bogner and Barr, 2000; Fourné et al., 2014) or with various individual experiences. Therefore, they need to have or develop some sort of shared understanding of the environmental changes and paths for future of the firm.

\section{DIRECTIONS FOR FUTURE RESEARCH}

Based on this review and proposed framework (shown in Figure 3), I identified future research directions across the different causes, components and consequences of hypercompetition. The section below addresses the methodological and theoretical issues in the current literature and discusses a number of directions for future research.

\subsection{Methodological Issues}


This review of the hypercompetition literature also identified a number of methodological issues. First, the quest to define industry environments has long been an important topic of discussion (D’Aveni, 1999, 1994; Porter, 1985), but when these discussions drift into hypercompetitive environments, the current knowledge and insights regarding how to measure hypercompetition appear rather limited (e.g. Castrogiovanni, 2002; McNamara et al., 2003; Vaaler and McNamara, 2010). A major limitation in the theory of hypercompetition is that D'Aveni (1994) does not define how to measure or determine whether a market is hypercompetitive. As can be seen in Table 4, scholars have used different techniques to measure different variables, such as sustainability of business profit (e.g. McNamara et al., 2003; Vaaler and McNamara, 2010), industry dynamism (e.g. Castrogiovanni, 2002; Lindskov et al., 2020), and industry heterogeneity (e.g. Thomas and D'Aveni, 2009).

Table 4 about here

These measurements have provided with consistent (Hermelo and Vassolo, 2010; Thomas, 1996; Thomas and D'Aveni, 2009; Wiggins and Ruefli, 2005) and inconsistent (Castrogiovanni, 2002; Lindskov et al., 2020; McNamara et al., 2003; Vaaler and McNamara, 2010) empirical findings with the assumption of increasing hypercompetition. Based on this mixed bag of empirical findings, it could be that scholars have used techniques that are devised for more stable environments, as they do not directly measure hypercompetition. From the definitions of hypercompetition shown in Table 1, we know that hypercompetition is related to uncertainty (i.e. disequilibrium and volatility in firm performance), high rates of change (i.e. frequency of competitive actions) and high intensity of change (i.e. aggressiveness of competitors). However, these determinants are also similar to what Knecht 
(2013) uses to measure of industry dynamism. So, the question of how to measure or determine whether a region or industry is hypercompetitive still remains unanswered.

Another methodological issue is the lack of empirical evidence regarding what causes hypercompetition. Even though the special issue in Strategic Management Journal in 2010 was open for studies on the antecedents of hypercompetition, only a few articles have contributed with such links over the years. In this review, a few articles investigate the impact of exogenous changes on competitive advantage e.g. Hermelo and Vassolo (2010) who found that institutional changes affect the level of competition within an industry, but they also found that the regional-industry competition differences that can be explained by how developed the region is. At present, there is still room for empirical studies investigating the causes of hypercompetition. For example, scholars could focus on the frequency of competitive actions of stakeholders, and whether an increase in the competitive intensity causes hypercompetition.

\subsection{Theoretical Issues}

There is also room for improvement on the theoretical part. Research on hypercompetition has been growing steadily over the past 25 years, but more research is needed both on the general concept and its outcomes.

First, several scholars argue that hypercompetition has spread worldwide across both industries (Mattila, 2001; Thomas and D'Aveni, 2009) and regions (Hermelo and Vassolo, 2010; Ruiz et al., 2017). However, some scholars have still found context-specific differences in the level of competition (Hermelo and Vassolo, 2010; Lindskov et al., 2020; Ruiz et al., 2017; Vaaler and McNamara, 2010), which may suggest that hypercompetition comes in different forms. Similarly, the typology by Pacheco-De-Almeida (2010) suggests different types of environmental hypercompetition (i.e. 
innovative hypercompetition, imitative hypercompetition and dual hypercompetition), based on the speed of innovation and imitation in industries (or stages of the industry's life cycles). It may be that different types of hypercompetition exist if one uses Pacheco-De-Almeida's (2010) conceptualisation. However, the research field on hypercompetition lack of studies empirically testing this theory proposed by Pacheco-De-Almeida (2010). There is great potential in this area for research on the multiple types of hypercompetition, as the empirical evidence is rather limited.

Second, several scholars have provided research on the effects of hypercompetition, thereby proposing a need for certain organisational structures (i.e. from business model to resources and capabilities). However, suggested business models, strategic alliances, and resources and capabilities are numerous, making it difficult to get a clear overview of the potential links and patterns of within these suggested organisational new structures.

Third, research will also be needed to investigate how firms in hypercompetitive markets deal with the accelerating focus on social and environmental responsibilities from e.g. customers and governments. Today, firms are increasingly expected to have the necessary capabilities to deal with issues such as high level of pollution, good working conditions, and production waste. In hypercompetitive industries with constant disequilibrium, highly competitive pressure and only temporary advantages, is there room for initiatives consistent with CSR (Perrini et al., 2006)? How do firms that constantly fight for their survival use their resources and capabilities to create temporary advantages, and still address complicated long-term scoped issues such as equality in the workplace and fair working conditions?

\section{CONCLUSIONS AND IMPLICATIONS}


Over the years, strategic manoeuvring in hypercompetitive environments has become an important aspect of strategic management, and it is increasingly emphasised in the academic literature. The purpose of this article is to advance the knowledge on hypercompetition by conducting an SLR of 131 studies of hypercompetition with focus on the definitions, causes, and consequences of such an intense environment. Furthermore, provide a framework showing the causes and consequences of hypercompetition on different levels of analysis, and suggest directions for future research.

\subsection{Managerial implications}

The review findings have several implications for managers. In particular, I highlight three managerial implications: (1) action-based strategy, (2) the determinants of hypercompetition, and (3) the importance for managers of accurately establishing their firm's competitive situation.

First, scholars have typically taught managers to seek long-term strategies and competitive advantages, but under hypercompetition this type of strategy would make firms inflexible and slow to change. As D’Aveni (1994: 6) says, “today’s strengths become tomorrow’s weaknesses so quickly that sustaining advantages is nearly impossible”. Thus, if managers put effort into sustaining advantages, they may actually undermine the dynamic competitiveness of the firm. Based on the findings of the review, the primary implication of hypercompetition literature is that firms cannot enjoy long-term advantage, but have to rethink their strategies. In hypercompetitive markets, managers need a dynamic strategy. D’Aveni (1994) argues that such a strategy is based on the actions or reactions of the firm. To illustrate, a firm acts to gain an advantage over its competitors, then the competitor reacts to neutralize that advantage (or build a new advantage), and then the first firm has to react to this action of its rival. Under hypercompetition, the frequency of 
these actions increases (Andrevski and Ferrier, 2019). Therefore, managers have to develop a strategy that focuses on these dynamic strategic interactions. More specifically, a firm needs to constantly develop temporary advantages through either innovating their products (i.e. disrupting their own advantages) or destroying the advantages of their rivals (i.e. imitation). A firm that survives and thrives in a 'hyper'-market does not remain static, but changes its market positioning, constantly develops new advantages, and tries to be one step ahead of the competitor.

Second, the thematic analysis of the hypercompetitive dimensions used in literature show that scholars have used a variety of characteristics and definitions to describe the phenomenon. The variety of definitions of hypercompetition may have made it difficult for managers to identify whether they are competing in a 'hyper'-market. A clear definition can help managers identify a hypercompetitive market. For example, if a manager increases the firm's frequency of competitive actions and observes that the advantages are more temporary than sustainable, it is more likely that the market has become hypercompetitive. The research framework presented in this paper may therefore help managers in the future to identify and understand the hypercompetitive market conditions.

Third, as previous studies (Lindskov et al., 2020; McNamara et al., 2003) and the results of this paper suggest, hypercompetition in one industry does not necessarily imply hypercompetition in another. Even though D'Aveni (1994) argues that hypercompetition has spread to different industries worldwide, the findings of other scholars tell a different story. This highlights the importance of determining the competitive situation within your own industry, rather than assuming hypercompetition. Failing to do so may lead to wasteful efforts to adapt their strategy to hypercompetition where it doesn't exist. 


\subsection{Summary of central findings}

The findings of this review can help explain why some markets become hypercompetitive, and how this may affect both industries, firms, individuals and teams. Hypercompetition is a state of intense rivalry, where firms are constantly creating new competitive advantages through either disrupting their own advantages or eroding those of competitors, thereby creating a temporary state of disequilibrium. The factors causing hypercompetition is the actions of stakeholders, which may affect the speed of technological innovation, market barriers, and rivalry. When markets have become hypercompetitive it affects both industries (e.g. increasing dynamism), firms (e.g. decreasing superior economic performance), and individuals and teams (e.g. flexible and dynamic management). Based on these insights, the review suggests that future research focus on the phenomenon of hypercompetition itself. Even though, several scholars argue that hypercompetition has spread across industries and regions, the current empirical evidence is mixed. This could be due to the lack of a clear definition on how to measure hypercompetition. On one hand, industries and regions may have become hypercompetitive, but on the other hand, it could also be that hypercompetition is more perceptual in its nature, as Makadok (1998) argues. If scholars and practitioners misjudge hypercompetition, the implications might be that scholars oversee or waste resources potential growth opportunities or fail to exploit their current advantages.

\section{REFERENCES}

Akhter, S. H. (2003) Strategic planning, hypercompetition, and knowledge management. Business Horizons, 46(1): 19-24.

Alcalde-Giraudo, A., Fernández-Hernández, R., Paradinas-Márquez, C., Sánchez-González, P., and García-Muiña, F. E. (2020) Marketing approach to Nordic tourism. Technological Forecasting and Social Change, 163(June 2020). 
Ali, A. A., Mahmood, A., Ikram, A., and Ahmad, A. (2020) Configuring the drivers and carriers of process innovation in manufacturing organizations. Journal of Open Innovation: Technology, Market, and Complexity, 6(4): 1-22.

Andrevski, G., and Ferrier, W. J. (2019) Does It Pay to Compete Aggressively? Contingent Roles of Internal and External Resources. Journal of Management, 45(2): 620-644.

Atesci, K., Bhagwatwar, A., Deo, T., Desouza, K. C., and Baloh, P. (2010) Business process outsourcing: A case study of Satyam Computers. International Journal of Information Management, 30(3): 277-282.

Aupperle, K. E. (1996) Spontaneous Organizational Reconfiguration: A Historical Example Based on Xenophon's Anabasis. Organization Science, 7(4): 445-460.

Baaij, M., Greeven, M., and Van Dalen, J. (2004) Persistent superior economic performance, sustainable competitive advantage, and schumpeterian innovation: Leading established computer firms 1954-2000. European Management Journal, 22(5): 517-531.

Barney, J. (1991) Firm Resources and Sustained Competitive Advantage. Journal of Management, 17(1): 99-120.

Bayraktar, A., and Ndubisi, N. O. (2014) The role of organizational mindfulness in firms' globalization and global market performance. Journal of Research in Marketing and Entrepreneurship, 16(1): 26-46.

Bettis, R. A., and Hitt, M. A. (1995) The New Competitive Landscape. Strategic Management Journal, 16: 7-19.

Bogner, W. C., and Barr, P. S. (2000) Making Sense in Hypercompetitive Environments: A Cognitive Explanation for the Persistence of High Velocity Competition. Organization Science, 11(2): 212226.

Breschi, S., Malerba, F., and Orsenigo, L. (2000) Technological regimes and schumpeterian patterns of innovation. Economic Journal, 110(463): 388-410.

Burke, A., and van Stel, A. (2014) Entry and exit in disequilibrium. Journal of Business Venturing, 29(1): 174-192.

Castrogiovanni, G. J. (2002) Organization Task Environments: Have they Changed Fundamentally over Time? Journal of Management, 28(2): 129-150.

Chattopadhyay, U., and Bhawsar, P. (2017) Effects of Changing Business Environment on Organization Performance: The Case of HMT Watches Ltd. South Asian Journal of Business and Management Cases, 6(1): 36-46.

Chen, M.-J., Lin, H.-C., and Michel, J. G. (2010) Navigating in a hypercompetitive environment: the roles of action aggressiveness and TMT integration. Strategic Management Journal, 31(13): 14101430.

Christensen, M., and Knudsen, T. (2008) Entry and exit decisions in flexible teams. Journal of International Business Studies, 39(8): 1278-1292.

Craig, T. (1996) The Japanese Beer Wars: Initiating and Responding to Hypercompetition in New Product Development. Organization Science, 7(3): 302-321.

D’Aveni, R. (1999) Strategic Supremacy through Disruption and Dominance. Sloan Management Review, 40(3): 127-135.

D’Aveni, R. A. (1994) Hypercompetition. Managing the Dynamics of Stratgic Maneuvering (1st ed.). Free Press.

D’Aveni, R. A., Dagnino, G. B., and Smith, K. G. (2010) The Age of Temporary Advantage. Strategic Management Journal, 31: 1371-1385. 
Dagnino, G. B., Picone, P. M., and Ferrigno, G. (2020) Temporary Competitive Advantage: A State-ofthe-Art Literature Review and Research Directions. International Journal of Management Reviews, 23: 85-115.

Dess, G. G., and Beard, D. W. (1984) Dimensions of Organizational Task Environments. Administrative Science Quarterly, 29(1): 52-73.

Drejer, A. (2002) Situations for innovation management: Towards a contingency model. European Journal of Innovation Management, 5(1): 4-17.

Eisenhardt, K. M., and Bourgeois, L. J. (1988) Politics of strategic decision making in high velocity environments: Toward a midrange theory. Academy of Management Journal, 31: 737-770.

Fiegenbaum, A., Thomas, H., and Tang, M. J. (2001) Linking hypercompetition and strategic group theories: Strategic maneuvering in the US insurance industry. Managerial and Decision Economics, 22(4-5): 265-279.

Foss, N. J., and Knudsen, T. (2003) The resource-based tangle: Towards a sustainable explanation of competitive advantage. Managerial and Decision Economics, 24(4): 291-307.

Fourné, S. P. L., Jansen, J. J. P., and Mom, T. J. M. (2014) Strategic agility in MNEs: Managing tensions to capture opportunities across emerging and established markets. California Management Review, 56(3): 13-38.

Gallo, M., and Gardiner, P. D. (2007) Triggers for a flexible approach to project management within UK financial services. International Journal of Project Management, 25(5): 446-456.

Galunic, D. C., and Eisenhardt, K. M. (1996) The Evolution of Intracorporate Domains: Divisional Charter Losses in High-Technology, Multidivisional Corporations. Organization Science, 7(3): 255-282.

Hanssen-Bauer, J., and Snow, C. C. (1996) Responding to Hypercompetition: The Structure and Processes of a Regional Learning Network Organization. Organization Science, 7(4): 413-427.

Harvey, M., Griffith, D., and Novicevic, M. (2000) Development of "Timescapes" to Effectively Manage Global Inter-organizational Relational Communications. European Management Journal, 18(6): 646-662.

Harvey, M., and Novicevic, M. M. (2001) The impact of hypercompetitive "timescapes" on the development of a global mindset. Management Decision, 39(6): 448-460.

Hermelo, F. D., and Vassolo, R. (2010) Institutional development and hypercompetition in emerging economies. Strategic Management Journal, 31(13): 1457-1473.

Hoisl, K., Gruber, M., and Conti, A. (2017) RandD team diversity and performance in hypercompetitive environments. Strategic Management Journal, 38(7): 1455-1477.

Ilinitch, A. Y., D’Aveni, R. A., and Lewin, A. Y. (1996) New Organizational Forms and Strategies for Managing in Hypercompetitive Environments. Organization Science, 7(3): 211-220.

Kaivo-oja, J. R. L., and Lauraeus, I. T. (2018) The VUCA approach as a solution concept to corporate foresight challenges and global technological disruption. Foresight, 20(1): 27-49.

Karuppan, C. M., and Kepes, S. (2006) The strategic pursuit of mix flexibility through operators' involvement in decision making. International Journal of Operations and Production Management, 26(9): 1039-1064.

Knecht, M. (2013) Diversification, Industry Dynamism, and Economic Performance. Wiesbaden: Springer Gabler.

Lahiri, S., Pérez-Nordtvedt, L., and Renn, R. W. (2008) Will the new competitive landscape cause your firm's decline? It depends on your mindset. Business Horizons, 51(4): 311-320.

Lee, C.-H., Venkatraman, N., Tanriverdi, H., and Iyer, B. (2010) Complementarity-based 
hypercompetition in the software industry: Theory and empirical test, 1990-2002. Strategic Management Journal, 31(13): 1431-1456.

Liao, J., Kickul, J. R., and Ma, H. (2009) Organizational dynamic capability and innovation: An empirical examination of internet firms. Journal of Small Business Management, 47(3): 263-286.

Lindskov, A., Sund, K. J., and Dreyer, J. K. (2020) The search for hypercompetition: Evidence from a nordic market study. Advanced online publication. Industry and Innovation.

Makadok, R. (1998) Can first-mover and early-mover advantages be sustained in an industry with low barriers to entry/imitation? Strategic Management Journal, 19(7): 683-696.

Mattila, A. S. (2001) The effectiveness of service recovery in a multi-industry setting. Journal of Services Marketing, 15(7): 583-596.

McNamara, G., Vaaler, P. M., and Devers, C. (2003) Same as it ever was: the search for evidence of increasing hypercompetition. Strategic Management Journal, 24(3): 261-278.

Nath, D., and Newell, S. E. (1998) Organizational responses to a hypercompetitive environment: A case study of Pepsi Canada. Journal of Business Research, 41(1): 41-48.

Nault, B. R., and Vandenbosch, M. B. (1996) Eating Your Own Lunch: Protection Through Preemption. Organization Science, 7(3): 342-358.

Ngamkroeckjoti, C., and Johri, L. M. (2003) Coping with hypercompetition in the financial services industry in Thailand: Environmental scanning practices of leaders and followers. International Journal of Bank Marketing, 21: 359-368.

Pacheco-de-Almeida, G. (2010) Erosion, time compression, and self-displacement of leaders in hypercompetitive environments. Strategic Management Journal, 31(13): 1498-1526.

Palmer, I., Dunford, R., Rura-Polley, T., and Baker, E. (2001) Changing forms of organizing: Dualities in using remote collaboration technologies in film production. Journal of Organizational Change Management, 14(2): 190-212.

Parayre, R., and Hurry, D. (2001) Corporate investment and strategic stability in hypercompetition. Managerial and Decision Economics, 22(4-5): 281-298.

Penrose, E. (1959) Theory of the Growth of the Firm. New York, John Wiley.

Perrini, F., Pogutz, S., and Tencati, A. (2006) Developing corporate social responsibility: a European perspective. Cheltenham, UK: Edward Elgar Publishing.

Peteraf, M. (1993) The Cornerstones of Competitive Advantage: A Resource-Based View. Strategic Management Journal, 14: 179-191.

Porter, M. E. (1980) Competitive Strategy: Techniques for Analyzing Industries and Competitors,. New York: The Free Press.

Porter, M. E. (1985) The Competitive Advantage: Creating and Sustaining Superior Performance. NY: Free Press.

Richardson, J. (1996) Vertical Integration and Rapid Response in Fashion Apparel. Organization Science, 7(4): 400-412.

Ruiz, S., Arvate, P., and Xavier, W. (2017) Superior economic performance in developed and developing countries. International Journal of Emerging Markets, 12(1): 93-107.

Saadatmand, M., Dabab, M. and Weber, C. 2018. Dynamics of Competition and Strategy: A Literature Review of Strategic Management Models and Frameworks. 2018 Portland International Conference on Management of Engineering and Technology (PICMET), Honolulu, HI, pp. 1-14. Schneider, M. (2002) A Stakeholder Model of Organizational Leadership. Organization Science, 13(2): 209-220.

Schumpeter, J. A. (1934) The Theory of Economic Development: An Inquiry into Profits, Capital, 
Credit, Interest and the Business Cycle. Cambridge: MA Hardvard University Press.

Schumpeter, J. A. (1939) Business Cycles: A Theoretical, Historical, and Statistical Analysis of the Capitalist Process (1st ed.). Martino Publishing.

Sirmon, D. G., Hitt, M. A., Arregle, J.-L., and Campbell, J. T. (2010) The dynamic interplay of capability strengths and weaknesses: investigating the bases of temporary competitive advantage. Strategic Management Journal, 31(13): 1386-1409.

Thomas, L. G. (1996) The Two Faces of Competition: Dynamic Resourcefulness and the Hypercompetitive Shift. Organization Science, 7(3): 221-242.

Thomas, L. G., and D'Aveni, R. A. (2009) The changing nature of competition in the US manufacturing sector, 1950-2002. Strategic Organization, 7(4): 387-431.

Uhl-Bien, M., Marion, R., and McKelvey, B. (2007) Complexity Leadership Theory: Shifting leadership from the industrial age to the knowledge era. The Leadership Quarterly, 18(4): 298318.

Vaaler, P. M., and McNamara, G. (2010) Are technology-intensive industries more dynamically competitive? No and yes. Organization Science, 21(1): 271-289.

Vassolo, R., García-Sánchez, J., and Mesquita, L. (2017) Competitive Dynamics And Early Mover Advantages Under Economic Recessions. RAE Revista de Administracao de Empresas, 57(1): $22-36$.

Veliyath, R., and Fitzgerald, E. (2000) Firm capabilities, business strategies, customer preferences, and hypercompetitive arenas: The sustainability of competitive advantages with implications for firm competitiveness. Competitiveness Review, 10(1): 56-82.

Volberda, H. W. (1996) Toward the Flexible Form: How to Remain Vital in Hypercompetitive Environments. Organization Science, 7(4): 359-374.

Waard, E. de, Volberda, H., and Soeters, J. (2012) How to support sensing capabilities in highly volatile situations. Journal of Management and Organization, 18(6): 1986-2039.

Walumbwa, F. O., Maidique, M. A., and Atamanik, C. (2014) Decision-making in a crisis: What every leader needs to know. Organizational Dynamics, 43(4): 284-293.

Wiggins, R. R., and Ruefli, T. W. (2005) Schumpeter's ghost: Is hypercompetition making the best of times shorter? Strategic Management Journal, 26(10): 887-911.

Young, G., Smith, K. G., and Grimm, C. M. (1996) “Austrian” and Industrial Organization Perspectives on Firm-level Competitive Activity and Performance. Organization Science, 7(3): 243-254.

Zohar, A., and Morgan, G. (1996) Refining Our Understanding of Hypercompetition and Hyperturbulence. Organization Science, 7(4): 460-464. 


\section{TABLES AND FIGURES}

\begin{tabular}{|c|c|}
\hline Study & Definition \\
\hline D’Aveni (1994: 6) & $\begin{array}{l}\text { Hypercompetition is an environment of intense change, in which } \\
\text { flexible, aggressive, innovative competitors move into markets } \\
\text { easily and rapidly, eroding the advantages of the large and } \\
\text { established players }\end{array}$ \\
\hline Craig (1996: 303) & $\begin{array}{l}\text { The competitive environment described by Schumpeter, however, is } \\
\text { neither static nor predictable. It more closely resembles what is } \\
\text { today known as hypercompetition }\end{array}$ \\
\hline Volberda (1996: 360) & $\begin{array}{l}\text { The defining characteristic of hypercompetition is that firms, in their } \\
\text { struggle for control, continuously identify and develop new } \\
\text { advantages, thereby creating a temporary disequilibrium }\end{array}$ \\
\hline Harvey et al. (2000: 647) & $\begin{array}{l}\text { Hyper-competition has been viewed as the continuous generation of } \\
\text { new forms of competitive advantage through neutralizing, } \\
\text { destroying or rendering competitors competitive advantages obsolete }\end{array}$ \\
\hline $\begin{array}{l}\text { Parayre and Hurry (2001: } \\
\text { 281) }\end{array}$ & $\begin{array}{l}\text { Hypercompetition thus differs from normal competition, as it } \\
\text { involves a departure from the usual type of competitive equilibrium }\end{array}$ \\
\hline McNamara et al. (2003: 264) & $\begin{array}{l}\text { Hypercompetition increases the frequency of decision making and } \\
\text { consequently decreases the stability of markets and business } \\
\text { performance over time }\end{array}$ \\
\hline D’Aveni et al. (2010: 1382) & $\begin{array}{l}\text { Hypercompetition turns out to be a special case of Porter's five } \\
\text { forces (low barriers to entry and substitution, high power of buyers } \\
\text { and suppliers, and rising industry rivalry }\end{array}$ \\
\hline $\begin{array}{l}\text { Hermelo and Vassolo (2010: } \\
1459)\end{array}$ & $\begin{array}{l}\text { Hypercompetition is the phenomenon that increases the speed and } \\
\text { aggressiveness of competition in the four arenas reducing the } \\
\text { duration of the launch, exploitation, and counterattack cycles }\end{array}$ \\
\hline Hoisl et al. (2017: 1456) & $\begin{array}{l}\text { Hypercompetition is the result of strategic maneuvering among } \\
\text { competing firms }\end{array}$ \\
\hline Lindskov et al. (2020: 1) & $\begin{array}{l}\text { 'hypercompetition', a state of intense industry rivalry, making it } \\
\text { impossible to sustain competitive advantages }\end{array}$ \\
\hline
\end{tabular}


Globalization (Akhter, 2003; Ang and Cummings, 1997; Bayraktar and Ndubisi, 2014; Božič and Dimovski, 2019; Brown and Fai, 2006; Chen et al., 2010; Cox and Bridwell, 2007; Craig, 1996; Cule and Robey, 2004; D’Aveni, 1999; D’Aveni et al., 2010; Flier et al., 2001; Fourné et al., 2014; Hanssen-Bauer and Snow, 1996; Harvey and Griffith, 2007; Harvey and Novicevic, 2001, 2002; Hermelo and Vassolo, 2010; Ilinitch et al., 1996; Khan and Azmi, 2005; Kiessling et al., 2004; Lahiri et al., 2008; McNamara, Vaaler, and Devers, 2003; Panigrahi, 2019; Richardson, 1996; Rindova and Kotha, 2001; Schneider, 2002; Sternberg et al., 2019; Thomas, 1996; Uhl-Bien et al., 2007; Veliyath and Fitzgerald, 2000; Walumbwa et al., 2014)

Technological revolution (Akhter, 2003; Ali et al., 2020; Ang and Cummings, 1997; Bogner and Barr, 2000; Božič and Dimovski, 2019; Chen et al., 2010; Christensen and Knudsen, 2008; Craig, 1996; D’Aveni, 1999; Drejer, 2002; Esper et al., 2007; Flier et al., 2001; Fourné et al., 2014; Grewal et al., 1999; Hanssen-Bauer and Snow, 1996; Harvey and Griffith, 2007; Harvey and Novicevic, 2001, 2002; Hermelo and Vassolo, 2010; Hosseini, 2011; Ilinitch et al., 1996; Jarach, 2002; Khan and Azmi, 2005; Kiessling et al., 2004; Kulkarni and Sivaraman, 2019; Lahiri et al., 2008; Liu et al., 2006; Mathews, 2006; McNamara et al., 2003; Nath and Newell, 1998; Panigrahi, 2019; Parayre and Hurry, 2001; Richardson, 1996; Rindova and Kotha, 2001; Ruiz et al., 2017; Schneider, 2002; Sternberg et al., 2019; Thomas, 1996; Uhl-Bien et al., 2007; Veliyath and Fitzgerald, 2000; Walumbwa et al., 2014)

Demographic and socio-economic changes (Akhter, 2003; Ali et al., 2020; Chattopadhyay and Bhawsar, 2017; Craig, 1996; Drejer, 2002; Esper et al., 2007; Flier et al., 2001; Fourné et al., 2014; Harvey and Novicevic, 2001; Hermelo and Vassolo, 2010; Ilinitch et al., 1996; Kiessling et al., 2004; Lahiri et al., 2008; Nath and Newell, 1998; Ngamkroeckjoti and Johri, 2003; Ruiz et al., 2017; Schneider, 2002; Uhl-Bien et al., 2007; Veliyath and Fitzgerald, 2000)

Institutional context and regulations (Akhter, 2003; Ang and Cummings, 1997; Bogner and Barr, 2000; Brown and Maylor, 2005; Chattopadhyay and Bhawsar, 2017; Cox and Bridwell, 2007; Craig, 1996; Flier et al., 2001; Harvey and Griffith, 2007; Harvey and Novicevic, 2002; Hermelo and Vassolo, 2010; Lahiri et al., 2008; Ngamkroeckjoti and Johri, 2003; Panigrahi, 2019; Ruiz et al., 2017; Schneider, 2002; Uhl-Bien et al., 2007; Veliyath and Fitzgerald, 2000)

Customers (Akhter, 2003; Ali et al., 2020; Bogner and Barr, 2000; Castrogiovanni, 2002; Chattopadhyay and Bhawsar, 2017; Craig, 1996; Cule and Robey, 2004; D’Aveni, 1999; D'Aveni and Dagnino, 2010; Fourné et al., 2014; Grewal et al., 1999; Hanssen-Bauer and Snow, 1996; Hosseini, 2011; Khan and Azmi, 2005; Kulkarni and Sivaraman, 2019; Lahiri et al., 2008; Liu et al., 2006; Mathews, 2006; Nath and Newell, 1998; Ngamkroeckjoti and Johri, 2003; Parayre and Hurry, 2001; Sternberg et al., 2019; Thomas, 1996; Walumbwa et al., 2014)

Table 2. The past research describing the causes of hypercompetition 


\section{Individual-level}

Dynamism (Castrogiovanni, $\quad$ Firm performance (Andrevski 2002; Chen et al., 2010; Galunic and Eisenhardt, 1996; Hermelo and Vassolo, 2010; Lahiri et al., 2008; Lindskov et al., 2020; McNamara et al., 2003; Rindova and Kotha, 2001; Thomas, 1996; Vaaler and McNamara, 2010; Wiggins and Ruefli, 2005)

Munificence (Castrogiovanni, 2002; Lindskov, Sund and Dreyer, 2020; McNamara et al., 2003; Sirmon et al., 2010; Thomas, 1996; Wiggins and Ruefli, 2005)

Complexity (Castrogiovanni, 2002; Lee et al., 2010; Selsky et al., 2007; Thomas, 1996; Thomas and D'Aveni, 2009; Volberda, 1996) and Ferrier, 2019; Chen et al., 2010; Hermelo and Vassolo, 2010; Hinterhuber, 2013; Lindskov et al., , 2020; McNamara et al., 2003; Pacheco-De-Almeida, 2010; Panigrahi, 2019; Ruiz et al., 2017; Thomas, 1996; Thomas and D'Aveni, 2009; Vaaler and McNamara, 2010; Young et al.,1996)

Market share (Andrevski and Ferrier, 2019; Banker et al., 2013; Craig, 1996; Ferrier et al., 1999; Gimeno and Woo, 1996; Hoisl et al., 2017; Lee et al., 2010; Li and Chuang, 2001; Makadok, 1998; Nault and Vandenbosch, 1996; Parayre and Hurry, 2001; Vaaler and McNamara, 2010; Wiggins and Ruefli, 2005)

Business mortality (Amezcua et al., 2019; Kim and Kogut, 1996; Lindskov et al., 2020; McNamara et al., 2003; Vaaler and McNamara, 2010)

\section{Competitive actions}

(Andrevski and Ferrier, 2019; Chen et al., 2010; Ferrier et al., 1999; Lengnick-Hall and Wolff, 1999; Li and Chuang, 2001; Ravichandran, 2018; Rindova et al., 2010; Sirmon et al., 2010)

Organizational structure Business models (Adeleye, 2015; Akhter, 2003; Aupperle,

\section{Managerial capabilities}

(Akhter, 2003; Christensen and Knudsen, 2008; Esper et al., 2007; Foss and Klein, 2014; Gallo and Gardiner, 2007; Gómez-Gras and Verdú-Jover, 2005; Halbesleben et al., 2003; Kaivo-oja and Lauraeus, 2018; Karuppan and Kepes, 2006; Lahiri et al., 2008; LengnickHall and Wolff, 1999; Mathews, 2006; Ritala, 2013; Selsky et al., 2007; Shang et al., 2010; Sirmon et al., 2010; Smith et al., 2010; Uhl-Bien et al., 2007; Volberda, 1996;

Waard et al., 2012; Walumbwa, Maidique, and Atamanik, 2014)

Sensing capabilities (Bayraktar and Ndubisi, 2014; Bogner and Barr, 2000; Drejer, 2002;

Fourné et al., 2014; Harvey and Novicevic, 2001; Lahiri et al., 2008; Roberts and Grover, 2012; Shang et al., 2010; Waard et al., 2012)

Teams (Bogner and Barr, 2000; Chen et al., 2010; Christensen and Knudsen, 2008; Fourné et al., 2014; Harvey and Griffith, 2007; Hoisl et al., 2017; Karuppan and Kepes, 2006) 


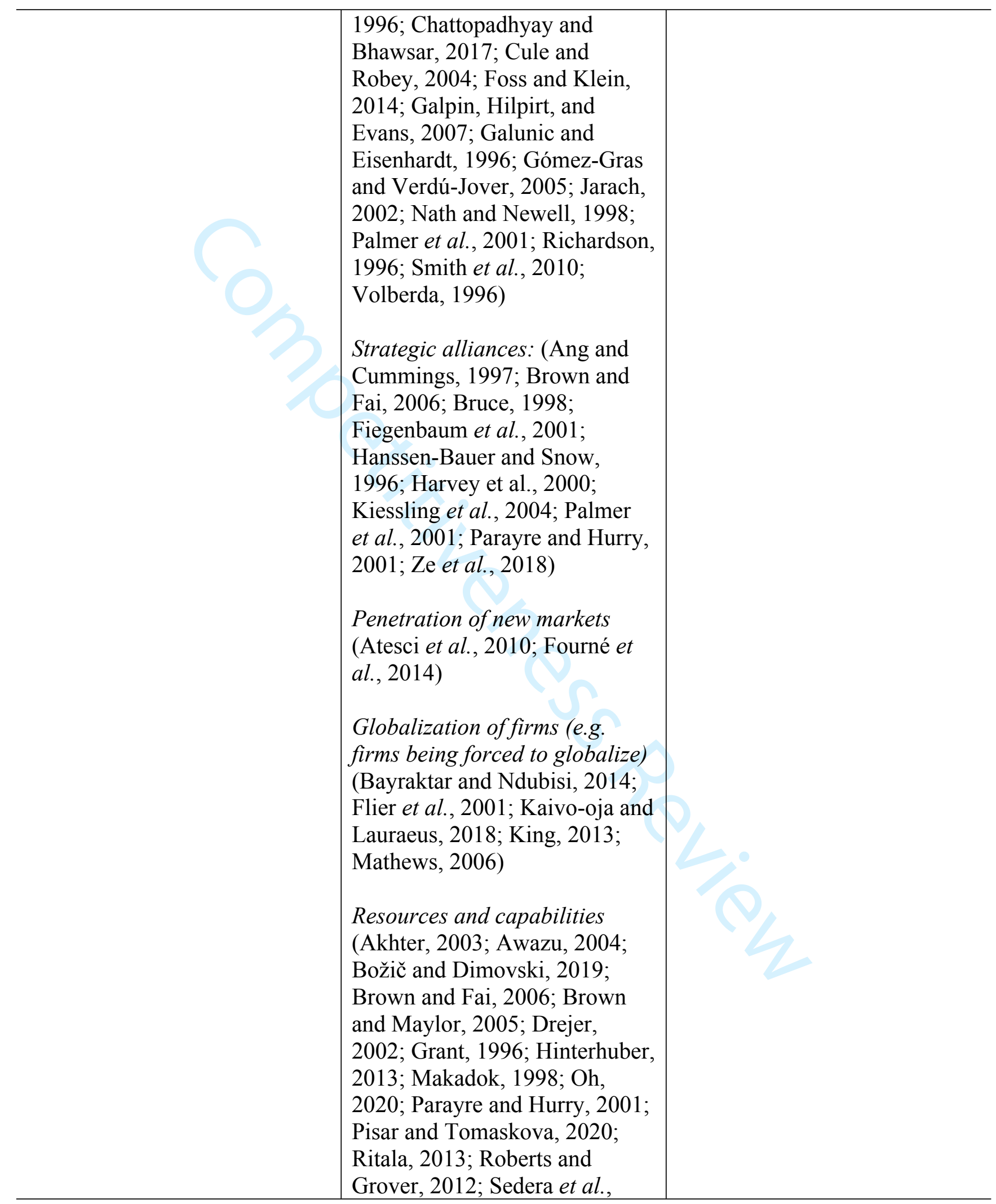


2016; Shang et al., 2010; Veliyath and Fitzgerald, 2000; Waard et al., 2012)

Product life cycle* (Ali et al., 2020; Bruce, 1998;

Castrogiovanni, 2002;

Chattopadhyay and Bhawsar, 2017; D'Aveni and Dagnino, 2010; Drejer, 2002; Esper et al., 2007; Gómez-Gras and VerdúJover, 2005; Hanssen-Bauer and Snow, 1996; Harvey and Griffith, 2007; Harvey and Novicevic, 2002; Hermelo and Vassolo, 2010; Hoisl et al., 2017; Hosseini, 2011; Ilinitch et al., 1996; Javalgi et al., 2006; Kaivo-oja and Lauraeus, 2018; Karuppan and Kepes, 2006; Khan and Azmi, 2005; Kiessling et al., 2004; Kim and Kogut, 1996; King, 2013; Kriz et al., 2014; Kulkarni and Sivaraman, 2019; Lahiri et al., 2008; Liu et al., 2006; Malhotra and Majchrzak, 2004; McNamara et al., 2003; Paap and Katz, 2004; Pacheco-deAlmeida, 2010; Palmer et al., 2001; Panigrahi, 2019; Parayre and Hurry, 2001; Richardson, 1996; Rindova et al., 2010; Sternberg et al., 2019; Vaaler and McNamara, 2010)

Table 3. the past research on the competitive and strategic implications of hypercompetition *These research papers do not measure "PLC", but only use the term to describe the effects of hypercompetition. 


\begin{tabular}{|c|c|c|c|c|}
\hline Author & Sample & Method(s) & Measure(s) & Findings \\
\hline Thomas (1996) & $\begin{array}{l}\text { U.S., } \\
\text { Manufacturing } \\
\text { sector } \\
\text { (including } \\
\text { multiple } \\
\text { industries), } \\
\text { 1958-91 }\end{array}$ & $\begin{array}{l}\text { Autoregressive } \\
\text { models; linear- } \\
\text { nonlinear models; } \\
\text { variance regressions }\end{array}$ & $\begin{array}{l}\text { The resourcefulness of } \\
\text { industries and intra-industry } \\
\text { variances in performance; } \\
\text { rivalry; The impact of growth } \\
\text { in industry shipments and } \\
\text { prices on firm value }\end{array}$ & $\begin{array}{l}\text { Increasing industry rivalry is } \\
\text { associated with lower market } \\
\text { performance; } \\
\text { Growth in shipment had no } \\
\text { significant impact of firm value; } \\
\text { Increasing concentration in market } \\
\text { structure, are associated with } \\
\text { decreasing variance in } \\
\text { performance. }\end{array}$ \\
\hline $\begin{array}{l}\text { Castrogiovanni } \\
(2002)\end{array}$ & $\begin{array}{l}\text { U.S., } \\
\text { Manufacturing } \\
\text { sector } \\
\text { (including } \\
\text { established } \\
\text { industries and } \\
\text { new } \\
\text { industries), } \\
\text { 1967-92 }\end{array}$ & $\begin{array}{l}\text { Generalized least } \\
\text { squares }\end{array}$ & $\begin{array}{l}\text { Environmental munificence, } \\
\text { dynamism and complexity. } \\
\text { New industries face greater } \\
\text { environmental munificence, } \\
\text { dynamism and complexity } \\
\text { than established industries. }\end{array}$ & $\begin{array}{l}\text { Munificence decreased over time; } \\
\text { Dynamism and Complexity did not } \\
\text { increase over time; } \\
\text { New industries did not face greater } \\
\text { environmental munificence than } \\
\text { established industries. } \\
\text { New industries faced greater } \\
\text { dynamism and complexity than } \\
\text { established industries. }\end{array}$ \\
\hline $\begin{array}{l}\text { Hermelo and } \\
\text { Vassolo (2010) }\end{array}$ & $\begin{array}{l}\text { Latin America, } \\
\text { 1990-2006 }\end{array}$ & $\begin{array}{l}\text { Kolmogorov- } \\
\text { Smirnov approach } \\
\text { and Event History } \\
\text { Analysis; }\end{array}$ & $\begin{array}{l}\text { Persistent Superior Economic } \\
\text { Performance of firms and } \\
\text { industries; } \\
\text { SEP decreases over time; } \\
\text { The development of } \\
\text { institutions decreases SEP; } \\
\text { The hazard of exiting SEP, } \\
\text { depending on whether the } \\
\text { firm is domestic or multi- } \\
\text { country firms. }\end{array}$ & $\begin{array}{l}\text { Higher levels of PSEP in Latin } \\
\text { America compared to the US; } \\
\text { A hypercompetitive shift in the last } \\
\text { decades; } \\
\text { The development of institutions } \\
\text { increases firms' rate of exit from } \\
\text { SEP }\end{array}$ \\
\hline $\begin{array}{l}\text { McNamara et } \\
\text { al. }(2003)\end{array}$ & $\begin{array}{l}\text { U.S., } \\
\text { Manufacturing } \\
\text { sector, } \\
1978-97\end{array}$ & $\begin{array}{l}\text { Autoregressive } \\
\text { model, Cox- } \\
\text { Proportional Hazard } \\
\text { rate model and a }\end{array}$ & $\begin{array}{l}\text { Abnormal business returns, } \\
\text { Business mortality, industry } \\
\text { dynamism and munificence }\end{array}$ & $\begin{array}{l}\text { No general evidence of increasing } \\
\mathrm{HC} \text {, but decreasing performance } \\
\text { from late- } 70 \text { s to late- } 80 \text { s. However, } \\
\text { then this trend reverses again and }\end{array}$ \\
\hline
\end{tabular}




\begin{tabular}{|c|c|c|c|c|}
\hline & & $\begin{array}{l}\text { composite fixed } \\
\text { effects model }\end{array}$ & & $\begin{array}{l}\text { performance and market stability } \\
\text { increases. }\end{array}$ \\
\hline $\begin{array}{l}\text { Wiggins and } \\
\text { Ruefli (2005) }\end{array}$ & $\begin{array}{l}\text { U.S., Multiple } \\
\text { industries, } \\
1978-97\end{array}$ & $\begin{array}{l}\text { Descriptive } \\
\text { statistics; Event } \\
\text { history analysis; } \\
\text { Pattern analysis }\end{array}$ & $\begin{array}{l}\text { The persistency of } \\
\text { performance decreases over } \\
\text { time; } \\
\text { Industry differences in the } \\
\text { level of competition; }\end{array}$ & $\begin{array}{l}\text { Persistency of performance } \\
\text { decreases over time; } \\
\text { Hypercompetition has spread to } \\
\text { several industries; } \\
\text { The performance patterns has } \\
\text { become more prevalent over time; }\end{array}$ \\
\hline $\begin{array}{l}\text { Thomas and } \\
\text { D'Aveni } \\
(2009)\end{array}$ & $\begin{array}{l}\text { U.S., } \\
\text { Manufacturing } \\
\text { sector, } \\
1950-2002\end{array}$ & $\begin{array}{l}\text { OLS regression } \\
\text { models; Fixed } \\
\text { effects models; }\end{array}$ & $\begin{array}{l}\text { Volatility for profits; } \\
\text { Increasing industry } \\
\text { heterogeneity; }\end{array}$ & $\begin{array}{l}\text { Increase in the within-industry } \\
\text { heterogenity of business returns; } \\
\text { Increase in volatility of firm profit; } \\
\text { Industry effects have decreased } \\
\text { over time; } \\
\text { Industry volatility and within- } \\
\text { industry heterogeneity are } \\
\text { becoming highly correlated }\end{array}$ \\
\hline $\begin{array}{l}\text { Vaaler and } \\
\text { McNamara } \\
(2010)\end{array}$ & $\begin{array}{l}\text { U.S., } \\
\text { Technology- } \\
\text { intensive (TI) } \\
\text { industries and } \\
\text { a broad sample } \\
\text { of non-TI } \\
\text { industries, } \\
\text { 1978-97 }\end{array}$ & $\begin{array}{l}\text { Autoregressive } \\
\text { model, Logit } \\
\text { models, Cox- } \\
\text { Proportional Hazard } \\
\text { rate model and a } \\
\text { composite fixed } \\
\text { effects model }\end{array}$ & $\begin{array}{l}\text { Abnormal business returns, } \\
\text { Market leadership; Business } \\
\text { mortality, industry dynamism }\end{array}$ & $\begin{array}{l}\text { No general evidence of increasing } \\
\text { hypercompetition, but Intra- } \\
\text { industry-specific trends. For high- } \\
\text { performing TI firms, the } \\
\text { performance stability declines over } \\
\text { time. }\end{array}$ \\
\hline $\begin{array}{l}\text { Lindskov et al. } \\
(2020)\end{array}$ & $\begin{array}{l}\text { Denmark, } \\
\text { Multiple } \\
\text { industries, } \\
\text { 1980-2017 }\end{array}$ & $\begin{array}{l}\text { Autoregressive } \\
\text { models; Kaplan } \\
\text { Meier; linear } \\
\text { regression model; a } \\
\text { composite fixed } \\
\text { effects model }\end{array}$ & $\begin{array}{l}\text { Abnormal business returns, } \\
\text { Firm survival, industry } \\
\text { dynamism and munificence }\end{array}$ & $\begin{array}{l}\text { No general trend of increasing } \\
\text { hypercompetition across industries. } \\
\text { Industry differences in the level of } \\
\text { competition. }\end{array}$ \\
\hline
\end{tabular}




\section{FIGURES}

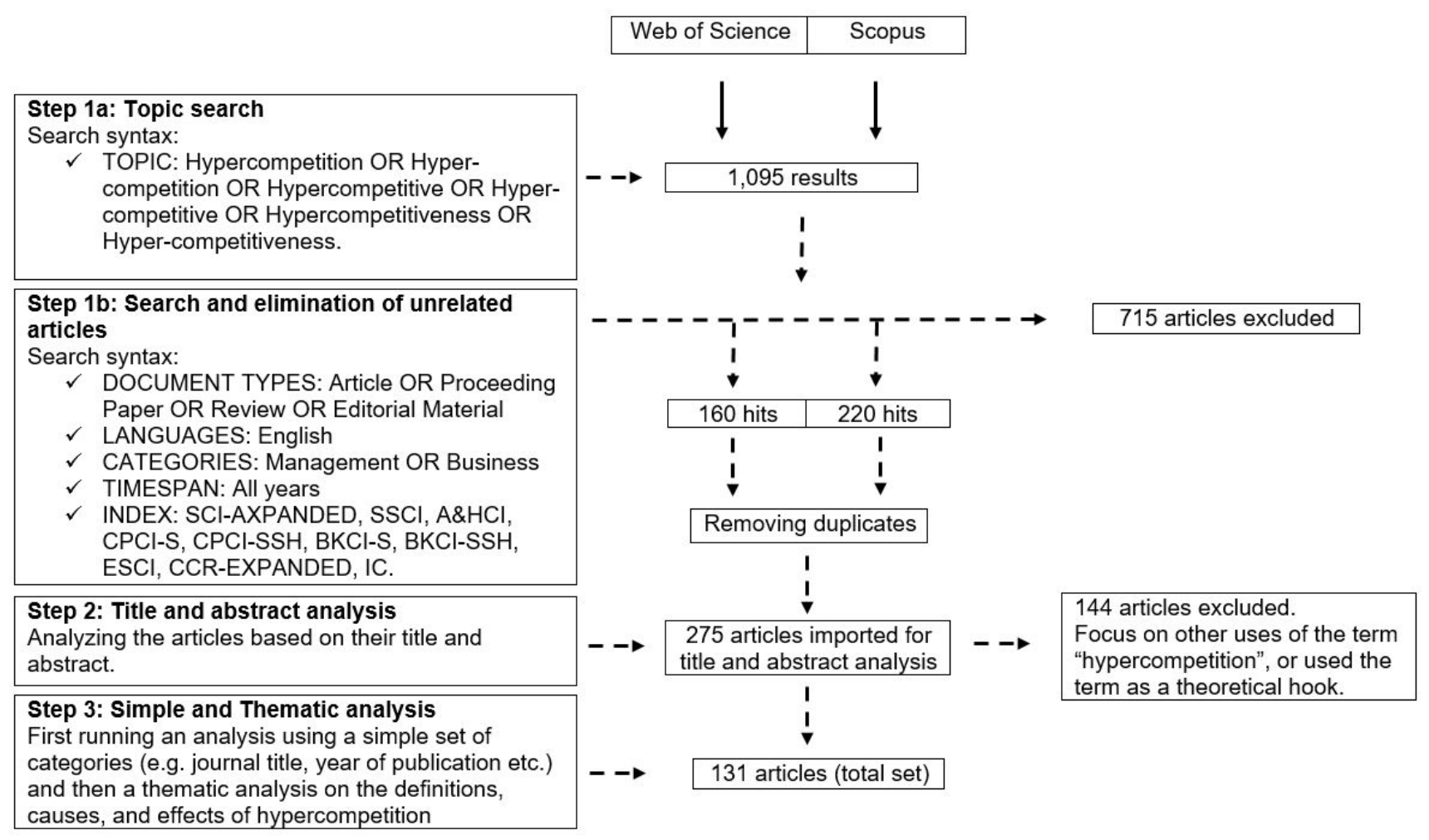

Figure 1. Search Syntax of the Review

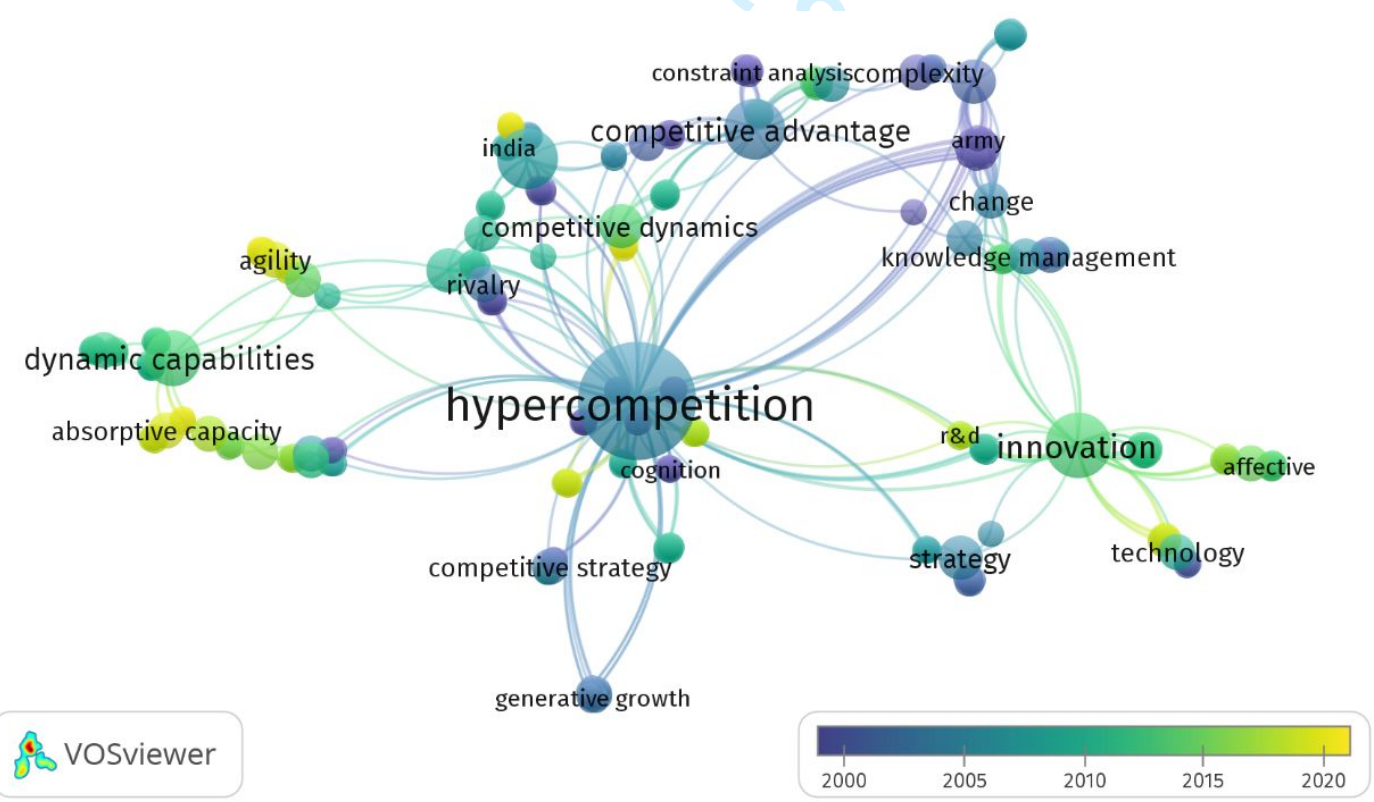

Figure 2: Network visualization map and overlay visualization of author keywords in Hypercompetition research (1996-2020) 


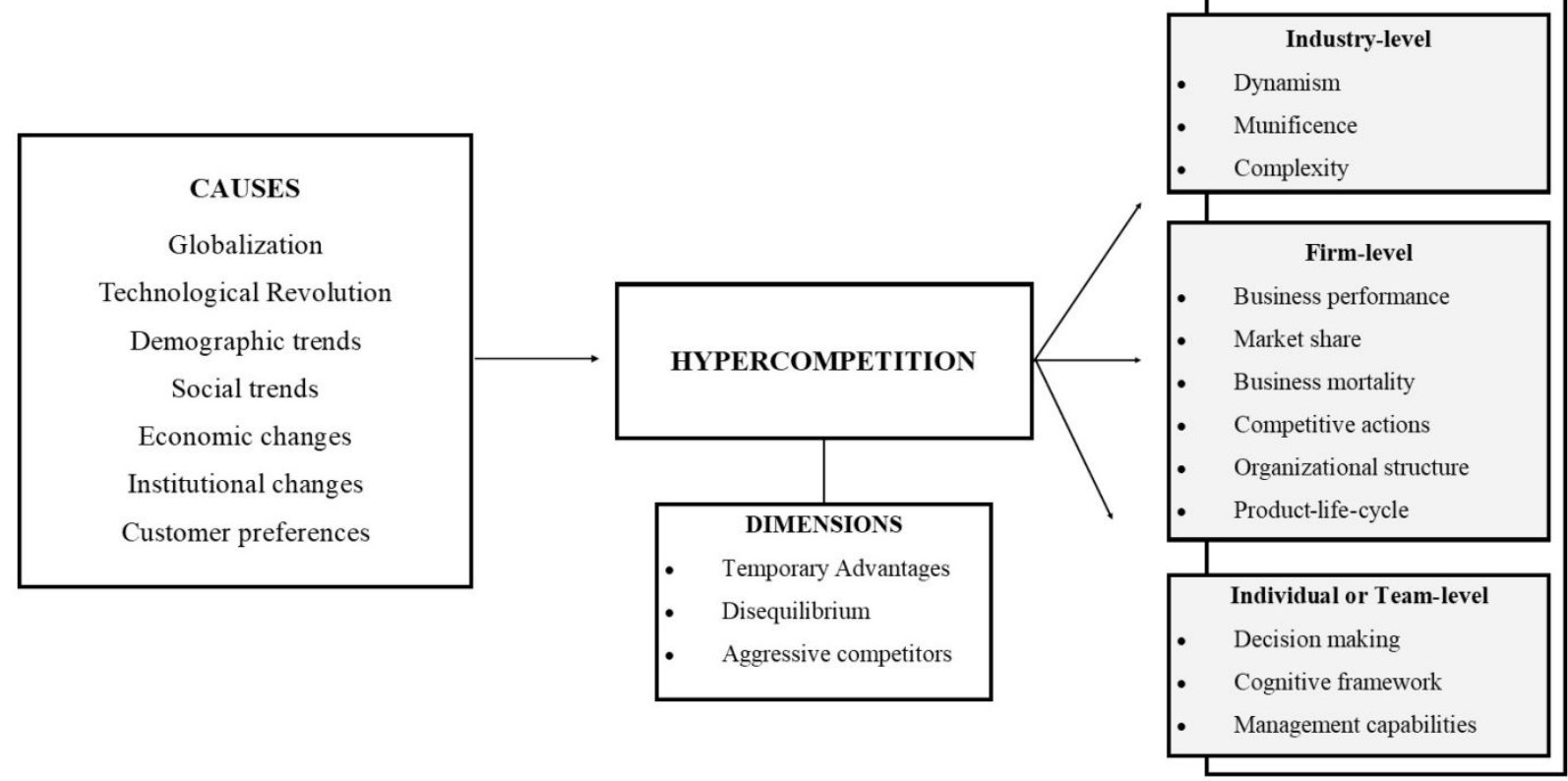

Figure 3: Research framework of Hypercompetition 
1. Adeleye, I. 2015. Accelerating corporate transformation in emerging markets: The case of firstbank. South Asian Journal of Business and Management Cases, 4(2): 182-191.

2. Akhter, S. H. 2003. Strategic planning, hypercompetition, and knowledge management. Business Horizons, 46(1): 19-24.

3. Ali, A. A., Mahmood, A., Ikram, A., and Ahmad, A. 2020. Configuring the drivers and carriers of process innovation in manufacturing organizations. Journal of Open Innovation: Technology, Market, and Complexity, 6(4): 1-22.

4. Almirall, E., Lee, M., and Majchrzak, A. 2014. Open innovation requires integrated competition-community ecosystems: Lessons learned from civic open innovation. Business Horizons, 57(3): 391-400.

5. Amezcua, A., Ratinho, T., Plummer, L. A., and Jayamohan, P. 2019. Organizational sponsorship and the economics of place: How regional urbanization and localization shape incubator outcomes. Journal of Business Venturing, (November 2018).

6. Andrevski, G., and Ferrier, W. J. 2019. Does It Pay to Compete Aggressively? Contingent Roles of Internal and External Resources. Journal of Management, 45(2): 620-644.

7. Ang, S., and Cummings, L. L. 1997. Strategic Response to Institutional Influences on Information Systems Outsourcing. Organization Science, 8(3): 235-256.

8. Atesci, K., Bhagwatwar, A., Deo, T., Desouza, K. C., and Baloh, P. 2010. Business process outsourcing: A case study of Satyam Computers. International Journal of Information Management, 30(3): 277-282.

9. Aupperle, K. E. 1996. Spontaneous Organizational Reconfiguration: A Historical Example Based on Xenophon's Anabasis. Organization Science, 7(4): 445-460.

10. Awazu, Y. 2004. Informal network players, knowledge integration, and competitive advantage. Journal of Knowledge Management, 8(3): 62-70.

11. Banker, R., Ca, Z., Menon, N. M., and Mudambi, R. 2013. The red queen in action: The longitudinal effects of capital investments in the mobile telecommunications sector. Industrial and Corporate Change, 22(5): 1195-1228.

12. Barnett, M. L. 2005. Paying attention to real options. R and D Management, 35(1): 61-72.

13. Bayraktar, A., and Ndubisi, N. O. 2014. The role of organizational mindfulness in firms' globalization and global market performance. Journal of Research in Marketing and Entrepreneurship, 16(1): 26-46.

14. Bogner, W. C., and Barr, P. S. 2000. Making Sense in Hypercompetitive Environments: A Cognitive Explanation for the Persistence of High Velocity Competition. Organization Science, 11(2): 212-226.

15. Boyt, T., and Harvey, M. 1997. Classification of industrial services A model with strategic implications. Industrial Marketing Management, 26(4): 291-300.

16. Božič, K., and Dimovski, V. 2019. Business intelligence and analytics use, innovation ambidexterity, and firm performance: A dynamic capabilities perspective. Journal of Strategic Information Systems, 28(4): 101578.

17. Bragge, J., Kauppi, K., Ahola, T., Aminoff, A., Kaipia, R., Tanskanen, K. 1997. Unveiling the intellectual structure and evolution of external resource management research: Insights from a bibliometric study. Journal of Business Research, 97: 141-159. 
18. Brown, S., and Fai, F. 2006. Strategic resonance between technological and organisational capabilities in the innovation process within firms. Technovation, 26(1): 60-75.

19. Brown, S., and Maylor, H. 2005. Strategic resonant firms, mass producers, big fish and flat liners: A study of policies, practices and performance in innovation. Technovation, 25(4): 307-319.

20. Bruce, K. 1998. Can you align IT with business strategy? Strategy and Leadership, 26(5): 1620.

21. Castrogiovanni, G. J. 2002. Organization Task Environments: Have they Changed Fundamentally over Time? Journal of Management, 28(2): 129-150.

22. Chattopadhyay, U., and Bhawsar, P. 2017. Effects of Changing Business Environment on Organization Performance: The Case of HMT Watches Ltd. South Asian Journal of Business and Management Cases, 6(1): 36-46.

23. Chen, M.-J., Lin, H.-C., and Michel, J. G. 2010. Navigating in a hypercompetitive environment: the roles of action aggressiveness and TMT integration. Strategic Management Journal, 31(13): 1410-1430.

24. Chiang, A. H., Chen, W. H., and Wu, S. 2015. Does high supply chain integration enhance customer response speed? Service Industries Journal, 35(1-2): 24-43.

25. Christensen, M., and Knudsen, T. 2008. Entry and exit decisions in flexible teams. Journal of International Business Studies, 39(8): 1278-1292.

26. Cox, J., and Bridwell, L. 2007. Australian companies using globalization to disrupt the ancient wine industry. Competitiveness Review, 17(4): 209-221.

27. Craig, T. 1996. The Japanese Beer Wars: Initiating and Responding to Hypercompetition in New Product Development. Organization Science, 7(3): 302-321.

28. Cule, P. E., and Robey, D. 2004. A Dual-Motor, Constructive Process Model of Organizational Transition. Organization Studies, 25(2): 229-260.

29. D’Aveni, R. 1999. Strategic Supremacy through Disruption and Dominance. Sloan Management Review, 40(3): 127-135.

30. D'Aveni, R. 2010. How to escape the differentiation proliferation trap. Strategy and Leadership, 38(3): 44-49.

31. D’Aveni, R. A., Dagnino, G. B., and Smith, K. G. (2010) The Age of Temporary Advantage. Strategic Management Journal, 31: 1371-1385.

32. Drejer, A. 2002. Situations for innovation management: Towards a contingency model. European Journal of Innovation Management, 5(1): 4-17.

33. Esper, T. L., Fugate, B. S., and Davis-Sramek, B. 2007. Logistics Learning Capability: Sustaining the Competitive Advantage Gained Through Logistics Leverage. Journal of Business Logistics, 28(2): 57-82.

34. Ferrier, W. J., Smith, K. G., and Grimm, C. M. 1999. The Role of Competitive Action in Market Share Erosion and Industry Dethronement: A Study of Industry Leaders and Challengers. Academy of Management Journal, 42(4): 372-388.

35. Fiegenbaum, A., Thomas, H., and Tang, M. J. 2001. Linking hypercompetition and strategic group theories: Strategic maneuvering in the US insurance industry. Managerial and Decision Economics, 22(4-5): 265-279. 
36. Flier, B., van den Bosch, F. A. J., Volberda, H. W., Carnevale, C. A., Tomkin, N., et al. 2001. The Changing Landscape of the European Financial Services Sector. Long Range Planning, 34(2): 179-207.

37. Foss, B. N. J., and Klein, P. G. 2014. Why Managers Still Matter. MIT Sloan Management Review, 56(56110): 73-80.

38. Fourné, S. P. L., Jansen, J. J. P., and Mom, T. J. M. 2014. Strategic agility in MNEs: Managing tensions to capture opportunities across emerging and established markets. California Management Review, 56(3): 13-38.

39. Fransesca, B. A., Primiana, I., Effendi, N., and Herwany, A. 2016. Impact of coffee product packaging and labeling on purchase intentions with mediating of brand image. Academy of Strategic Management Journal, 15(Special issue 3): 150-154.

40. Gallo, M., and Gardiner, P. D. 2007. Triggers for a flexible approach to project management within UK financial services. International Journal of Project Management, 25(5): 446-456.

41. Galpin, T., Hilpirt, R., and Evans, B. 2007. The connected enterprise: beyond division of labor. Journal of Business Strategy, 28(2): 38-47.

42. Galunic, D. C., and Eisenhardt, K. M. 1996. The Evolution of Intracorporate Domains: Divisional Charter Losses in High-Technology, Multidivisional Corporations. Organization Science, 7(3): 255-282.

43. Gimeno, J., and Woo, C. Y. 1996. Hypercompetition in a Multimarket Environment: The Role of Strategic Similarity and Multimarket Contact in Competitive De-Escalation. Organization Science, 7(3): 322-341.

44. Gómez-Gras, J. M., and Verdú-Jover, A. J. 2005. TQM, structural and strategic flexibility and performance: An empirical research study. Total Quality Management and Business Excellence, 16(7): 841-860.

45. Grant, R. M. 1996. Prospering in Dynamically-Competitive Environments: Organizational Capability as Knowledge Integration. Organization Science, 7(4): 375-387.

46. Grewal, D., Levy, M., Mehrotra, A., and Sharma, A. 1999. Planning Merchandising Decisions to Account for. Journal of Retailing, 75(3): 405-424.

47. Gummesson, E. 1997. In search of marketing equilibrium: Relationship marketing versus hypercompetition. Journal of Marketing Management, 13(5): 421-430.

48. Halbesleben, J. R. B., Novicevic, M. M., Harvey, M. G., and Buckley, M. R. 2003. Awareness of temporal complexity in leadership of creativity and innovation: A competencybased model. The Leadership Quarterly, 14(4-5): 433-454.

49. Hanssen-Bauer, J., and Snow, C. C. 1996. Responding to Hypercompetition: The Structure and Processes of a Regional Learning Network Organization. Organization Science, 7(4): 413-427.

50. Harvey, M. G., and Griffith, D. A. 2007. The role of globalization, time acceleration, and virtual global teams in fostering successful global product launches. Journal of Product Innovation Management, 24(5): 486-501.

51. Harvey, M., Griffith, D., and Novicevic, M. 2000. Development of "Timescapes" to Effectively Manage Global Inter-organizational Relational Communications. European Management Journal, 18(6): 646-662.

52. Harvey, M., and Novicevic, M. M. 2001. The impact of hypercompetitive "timescapes" on the development of a global mindset. Management Decision, 39(6): 448-460. 
71. Kulkarni, B., and Sivaraman, V. 2019. Making a Blue Ocean Shift: Tata Ace captures a new market. Journal of Business Strategy.

72. Lahiri, S., Pérez-Nordtvedt, L., and Renn, R. W. 2008. Will the new competitive landscape cause your firm's decline? It depends on your mindset. Business Horizons, 51(4): 311-320.

73. Leal-Rodriguez, A. L. 2019. Generating customer value through the boosting of relationships and organisational innovativeness. Knowledge Management Research and Practice, 00(00): $1-12$.

74. Lee, C.-H., Venkatraman, N., Tanriverdi, H., and Iyer, B. 2010. Complementarity-based hypercompetition in the software industry: Theory and empirical test, 1990-2002. Strategic Management Journal, 31(13): 1431-1456.

75. Lengnick-Hall, C. A., and Wolff, J. A. 1999. Similarities and contradictions in the core logic of three strategy research streams. Strategic Management Journal, 20(12): 1109-1132.

76. Li, S., and Chuang, Y. 2001. Racing for market share: Hypercompetition and the performance of multiunit-multimarket firms. ADVANCES IN STRATEGIC MANAGEMENT : A RESEARCH ANNUAL, 18: 329-355.

77. Liao, J., Kickul, J. R., and Ma, H. 2009. Organizational dynamic capability and innovation: An empirical examination of internet firms. Journal of Small Business Management, 47(3): 263-286.

78. Lindskov, A., Sund, K. J., and Dreyer, J. K. 2020. The search for hypercompetition: Evidence from a nordic market study. Industry and Innovation. Advanced online publication.

79. Liu, J. J., Qian, J. Y., and Chen, J. 2006. Technological learning and firm-level technological capability building: analytical framework and evidence from Chinese manufacturing firms. International Journal of Technology Management, 36(1/2/3): 190.

80. Mahto, R. V., Ahluwalia, S., and Walsh, S. T. 2018. The diminishing effect of VC reputation: Is it hypercompetition? Technological Forecasting and Social Change, 133(March): 229-237.

81. Makadok, R. 1998. Can first-mover and early-mover advantages be sustained in an industry with low barriers to entry/imitation? Strategic Management Journal, 19(7): 683-696.

82. Malhotra, A., and Majchrzak, A. 2004. Enabling knowledge creation in far-flung teams: Best practices for IT support and knowledge sharing. Journal of Knowledge Management, 8(4): $75-88$.

83. Mathews, P. 2006. The role of mentoring in promoting organisational competitiveness. Competitiveness Review, 16(2): 158-169.

84. Mattila, A. S. 2001. The effectiveness of service recovery in a multi-industry setting. Journal of Services Marketing, 15(7): 583-596.

85. McNamara, G., Vaaler, P. M., and Devers, C. 2003. Same as it ever was: the search for evidence of increasing hypercompetition. Strategic Management Journal, 24(3): 261-278.

86. Nath, D., and Newell, S. E. 1998. Organizational responses to a hypercompetitive environment: A case study of Pepsi Canada. Journal of Business Research, 41(1): 41-48.

87. Nault, B. R., and Vandenbosch, M. B. 1996. Eating Your Own Lunch: Protection Through Preemption. Organization Science, 7(3): 342-358.

88. Ngamkroeckjoti, C., and Johri, L. M. 2003. Coping with hypercompetition in the financial services industry in Thailand: Environmental scanning practices of leaders and followers. International Journal of Bank Marketing, 21: 359-368. 
89. Oh, C. H. 2020. The changing terrain of international strategy for Korean multinationals. Asian Business and Management, 19(2): 171-174.

90. Orr, S. 2019. Daring to tap external strategic resources: competitive advantage in global industries. Journal of Business Strategy, JBS-03-2018-0032.

91. Paap, J., and Katz, R. 2004. Anticipating disruptive innovation. Research Technology Management, 47(5): 13-22.

92. Pacheco-de-Almeida, G. 2010. Erosion, time compression, and self-displacement of leaders in hypercompetitive environments. Strategic Management Journal, 31(13): 1498-1526.

93. Palmer, I., Dunford, R., Rura-Polley, T., and Baker, E. 2001. Changing forms of organizing: Dualities in using remote collaboration technologies in film production. Journal of Organizational Change Management, 14(2): 190-212.

94. Panigrahi, R. 2019. Evaluating Level Efficiency Versus Growth Efficiency in the Indian Automobile Industry in a Non-parametric DEA Approach. Global Business Review, (1).

95. Parayre, R., and Hurry, D. 2001. Corporate investment and strategic stability in hypercompetition. Managerial and Decision Economics, 22(4-5): 281-298.

96. Pavlak, M., and Pisar, P. 2020. Strategic management controlling system and its importance for SMEs in the EU. Problems and Perspectives in Management, 18(3): 362-372.

97. Pisar, P., and Tomaskova, A. 2020. The importance of social networks for the SME's innovation potential in Industry 4.0. Innovative Marketing, 16(3): 48-61.

98. Powell, T. C., and Reinhardt, I. 2010. Rank friction: an ordinal approach to persistent profitability. Strategic Management Journal, 31(11): 1244-1255.

99. Priporas, C. V. 2019. Competitive intelligence practice in liquor retailing: evidence from a longitudinal case analysis. International Journal of Retail and Distribution Management, 47(9): 997-1010.

100. Rane, S. B., Narvel, Y. A. M., and Bhandarkar, B. M. 2019. Developing strategies to improve agility in the project procurement management (PPM) process: Perspective of business intelligence (BI). Business Process Management Journal, 26(1): 257-286.

101. Ravichandran, T. 2018. Exploring the relationships between IT competence, innovation capacity and organizational agility. Journal of Strategic Information Systems, 27(1): 22-42.

102. Richardson, J. 1996. Vertical Integration and Rapid Response in Fashion Apparel. Organization Science, 7(4): 400-412.

103. Rindova, V., Ferrier, W. J., and Wiltbank, R. 2010. Value from gestalt: how sequences of competitive actions create advantage for firms in nascent markets. Strategic Management Journal, 31(13): 1474-1497.

104. Rindova, V. P., and Kotha, S. 2001. Continuous "morphing": Competing through dynamic capabilities, form, and function. Academy of Management Journal, 44(6): 12631280 .

105. Ritala, P. 2013. Linking the unlinked: Knowledge-based perspective on non-routine change. Management Decision, 51(6): 1176-1189.

106. Roberts, N., and Grover, V. 2012. Investigating firm's customer agility and firm performance: The importance of aligning sense and respond capabilities. Journal of Business Research, 65(5): 579-585. 
107. Ruiz, S., Arvate, P., and Xavier, W. 2017. Superior economic performance in developed and developing countries. International Journal of Emerging Markets, 12(1): 93 107.

108. Schneider, M. 2002. A Stakeholder Model of Organizational Leadership. Organization Science, 13(2): 209-220.

109. Sedera, D., Lokuge, S., Grover, V., Sarker, Suprateek, and Sarker, Saonee. 2016. Innovating with enterprise systems and digital platforms: A contingent resource-based theory view. Information and Management, 53(3): 366-379.

110. Selsky, J. W., Goes, J., and Babüroğlu, O. N. 2007. Contrasting perspectives of strategy making: Applications in "hyper" environments. Organization Studies, 28(1): 71-94.

111. Shang, H., Huang, P., and Guo, Y. 2010. Managerial cognition: the sources of sustainable competitive advantage in hypercompetition: A case study. Nankai Business Review International, 1(4): 444-459.

112. Sharma, A. 2001. Consumer decision-making, salespeople's adaptive selling and retail performance. Journal of Business Research, 54(2): 125-129.

113. Sirmon, D. G., Hitt, M. A., Arregle, J.-L., and Campbell, J. T. 2010. The dynamic interplay of capability strengths and weaknesses: investigating the bases of temporary competitive advantage. Strategic Management Journal, 31(13): 1386-1409.

114. Smith, A. D., and Zeithaml, C. 1996. Garbage Cans and Advancing Hypercompetition: The Creation and Exploitation of New Capabilities and Strategic Flexibility in Two Regional Bell Operating Companies. Organization Science, 7(4): 388-399.

115. Smith, W. K., Binns, A., and Tushman, M. L. 2010. Complex Business Models: Managing Strategic Paradoxes Simultaneously. Long Range Planning, 43(2-3): 448-461.

116. Sternberg, E., LiPuma, V. J., and Warren, H. 2019. Fast flex: Strategic design for industrial real estate in the age of corporate agility. Journal of General Management, 44(3): $138-145$.

117. Thomas, L. G. 1996. The Two Faces of Competition: Dynamic Resourcefulness and the Hypercompetitive Shift. Organization Science, 7(3): 221-242.

118. Thomas, L. G., and D'Aveni, R. A. 2009. The changing nature of competition in the US manufacturing sector, 1950-2002. Strategic Organization, 7(4): 387-431.

119. Tran, H., Cahoon, S., and Chen, S. L. 2011. A quality management framework for seaports in their supply chains in the 21 st century. Asian Journal of Shipping and Logistics, 27(3): 363-386.

120. Uhl-Bien, M., Marion, R., and McKelvey, B. 2007. Complexity Leadership Theory: Shifting leadership from the industrial age to the knowledge era. The Leadership Quarterly, 18(4): 298-318.

121. Ushakov, D., Robu, E., Blagorazumnaia, O., and Kabaha, S. 2020. Transnationalized tourism: Hyper-advantages from global competitiveness. Journal of Environmental Management and Tourism, 11(6): 1316-1327

122. Vaaler, P. M., and McNamara, G. 2010. Are technology-intensive industries more dynamically competitive? No and yes. Organization Science, 21(1): 271-289.

123. Veliyath, R., and Fitzgerald, E. 2000. Firm capabilities, business strategies, customer preferences, and hypercompetitive arenas: The sustainability of competitive advantages with implications for firm competitiveness. Competitiveness Review, 10(1): 56-82. 
124. Volberda, H. W. 1996. Toward the Flexible Form: How to Remain Vital in Hypercompetitive Environments. Organization Science, 7(4): 359-374.

125. Waard, E. de, Volberda, H., and Soeters, J. 2012. How to support sensing capabilities in highly volatile situations. Journal of Management and Organization, 18(6): 1986-2039.

126. Walumbwa, F. O., Maidique, M. A., and Atamanik, C. 2014. Decision-making in a crisis: What every leader needs to know. Organizational Dynamics, 43(4): 284-293.

127. Weber, J. A. 1997. Exploring for competitive advantages in business markets. Industrial Marketing Management, 26(6): 531-554.

128. Wiggins, R. R., and Ruefli, T. W. 2005. Schumpeter's ghost: Is hypercompetition making the best of times shorter? Strategic Management Journal, 26(10): 887-911.

129. Young, G., Smith, K. G., and Grimm, C. M. 1996. "Austrian” and Industrial Organization Perspectives on Firm-level Competitive Activity and Performance.

Organization Science, 7(3): 243-254.

130. Ze, R., Kun, Z., Boadu, F., and Yu, L. 2018. The effects of boundary-spanning search, network ties, and absorptive capacity for innovation: A moderated mediation examination. Sustainability (Switzerland), 10(11).

131. Zohar, A., and Morgan, G. 1996. Refining Our Understanding of Hypercompetition and Hyperturbulence. Organization Science, 7(4): 460-464.

Table A1. The review sample (ordered chronologically)

\begin{tabular}{|c|c|}
\hline Study & Definition \\
\hline Akhter (2003) & $\begin{array}{l}\text { "accelerated change - is the watchword for understanding the new } \\
\text { landscape" (p. 2) }\end{array}$ \\
\hline $\begin{array}{l}\text { Andrevski and } \\
\text { Ferrier (2019) }\end{array}$ & $\begin{array}{l}\text { "In hypercompetitive environments, firms act under conditions of uncertainty } \\
\text { because knowledge is unevenly distributed across market participants and it } \\
\text { rapidly changes over time, so firms act with incomplete knowledge" (p. 624) }\end{array}$ \\
\hline $\begin{array}{l}\text { Ang and } \\
\text { Cummings (1997) }\end{array}$ & $\begin{array}{l}\text { "rapidly escalating competition based on new and continually shifting } \\
\text { product or geographic markets, frequent entry of unexpected competitors, } \\
\text { radical redefinition of market boundaries, rapidly changing technologies, and } \\
\text { short product life cycles" (p. 236) }\end{array}$ \\
\hline $\begin{array}{l}\text { Banker et al. } \\
\text { (2013) }\end{array}$ & "Intense rivalry among firms" (p. 1196) \\
\hline $\begin{array}{l}\text { Bogner and Barr } \\
(2000)\end{array}$ & $\begin{array}{l}\text { "Hypercompetition represents a state of competition with rapidly escalating } \\
\text { levels of competition and reduced periods of competitive advantage for firms" } \\
\text { (p. 212) } \\
\text { "Hypercompetitive industries are characterized by rapid changes in } \\
\text { environmental factors such as technology and regulation, relative ease of } \\
\text { entry and exit by rival firms, and ambiguous consumer demands" (p. 212) }\end{array}$ \\
\hline $\begin{array}{l}\text { Brown and Fai } \\
(2006)\end{array}$ & $\begin{array}{l}\text { "current competitive environment is increasingly characterised by rapid } \\
\text { technological changes in new and existing products, brought about, in part at } \\
\text { least, by enhanced levels of competition" (p. 62) }\end{array}$ \\
\hline
\end{tabular}


Bruce (1998) $\quad$ "Hyper-competitive markets bring pressure for firms to shorten product lifecycles, rapidly identify and penetrate new market segments, dramatically increase operational efficiencies, and disintermediate supply chains and distribution channels" (p. 1)

Chen et al. (2010) "an 'environment in which advantages are rapidly created and destroyed' (D’Aveni, 1994: 2)" (p. 1411)

"A hypercompetitive environment creates uncertainty and perceptual variation among industry players, who tend to have different interpretations and understandings of the nature, scope, pace, (Sutcliffe, 1994), and longterm viability (Dean and Sharfman, 1996) of changes" (p. 1415);

Christensen and "hypercompetition is seen as the primary cause of their [red. IT industries]
Knudsen (2008) emergence" (p. 1280)

"Hypercompetition refers to the shift in the rules of competition that was observed through the 1990s" (p. 1280)

"A highly turbulent environment has rapid variation in profit levels as well as high volatility of profit levels" (p. 1290)

Cox and Bridwell "in today's tumultuous world, the concept of a sustainable competitive (2007) Craig (1996) advantage is dangerously inflexible and out of date" (p. 210)

"The competitive environment described by Schumpeter, however, is neither static nor predictable. It more closely resembles what is today known as hypercompetition" (p. 303)

"which D'Aveni (1994) describes as a condition of 'rapidly escalating competition ... (in which) the frequency, boldness, and aggressiveness of dynamic movement by the players accelerates to create a condition of constant disequilibrium and change" (p. 303)

\begin{tabular}{l|l}
\hline D'Aveni (1999) & $\begin{array}{l}\text { "now the central focus of strategy is on understanding the relationship } \\
\text { between an environment's turbulence and the company's choice of strategy" } \\
\text { (p. 128) }\end{array}$ \\
\hline $\begin{array}{l}\text { D'Aveni and } \\
\text { Dagnino (2010) }\end{array}$ & $\begin{array}{l}\text { "as environments get more dynamic, they become more unpredictable and } \\
\text { (p. makn the creation of intended, planned strategies more difficult" }\end{array}$
\end{tabular}
(p. 1373)

"hypercompetitive shift toward more temporary advantage" (p. 1380)

“hypercompetition (defined by D'Aveni, 1994: 2 as 'an environment of fierce competition leading to unsustainable advantage or the decline in the sustainability of advantage')" (p. 1380)

"hypercompetition as a nonmunificent environment lacking in resources somewhat akin to a recession" (p. 1380)

Drejer (2002) $\quad$ "Hyper-competition, according to D'Aveni, is a competitive situation where the key competitive success factor is the ability to constantly develop new products, processes or services, providing the customer with increased functionality and performance" (p. 4-5) 
Fiegenbaum et al. (2001)

\begin{tabular}{|c|c|}
\hline & $\begin{array}{l}\text { "in a hypercompetitive environment, firms cannot count on a sustainable } \\
\text { competitive advantage, but must continuously develop themselves in new } \\
\text { directions" (p. 5) }\end{array}$ \\
\hline Esper et al. (2007) & $\begin{array}{l}\text { "Many industries have progressed from slow moving, stable oligopolies to } \\
\text { hypercompetitive environments characterized by intense and rapid } \\
\text { competitive moves, in which competitors strike quickly, unexpectedly, and } \\
\text { unconventionally and advantages are rapidly created and eroded" (p. 57) }\end{array}$ \\
\hline $\begin{array}{l}\text { Fiegenbaum et al. } \\
\text { (2001) }\end{array}$ & $\begin{array}{l}\text { "the major contribution of the hypercompetition paradigm is its concentration } \\
\text { on competitive dynamics and exploration of the patterns and pathways of } \\
\text { strategic maneuvering that take place among industrial competitors" (p. 265) } \\
\text { "hypercompetition can be viewed as either differentiated oligopoly or } \\
\text { monopolistic competition, but not as anything really 'new" (p. 266) } \\
\text { "hypercompetition is one among many possible types of oligopolistic } \\
\text { behavior" (p. 267) }\end{array}$ \\
\hline $\begin{array}{l}\text { Gallo and Gardiner } \\
(2007)\end{array}$ & $\begin{array}{l}\text { "Hyper-competition, the presence of unpredictability, increased complexity } \\
\text { and a rapid pace of change" (p. 446) }\end{array}$ \\
\hline $\begin{array}{l}\text { Gomez-Gras and } \\
\text { Verdu-Jover (2005) }\end{array}$ & $\begin{array}{l}\text { "Greater competition means volatile markets, shorter life cycles and more } \\
\text { sophisticated purchasers" (p. 842) } \\
\text { "an increase in discontinuity, uncertainty and chaos" (p. 844) }\end{array}$ \\
\hline Grant (1996) & $\begin{array}{l}\text { "hypercompetition are characteristic of product markets, dynamically } \\
\text { competitive conditions also are present in the markets for resources" (p. 376) }\end{array}$ \\
\hline Gummesson (1997) & $\begin{array}{l}\text { "In an environment of hypercompetition, advantages are rapidly created and } \\
\text { eroded" (p. 425) } \\
\text { "Hypercompetition is a constant state of disequilibrium" (p. 426) }\end{array}$ \\
\hline $\begin{array}{l}\text { Hanssen-Bauer and } \\
\text { Snow (1996) }\end{array}$ & $\begin{array}{l}\text { "Such environments are highly changeable and even discontinuous, requiring } \\
\text { organizations to respond flexibly and rapidly" (p. 413) }\end{array}$ \\
\hline $\begin{array}{l}\text { Harvey et al. } \\
(2000)\end{array}$ & $\begin{array}{l}\text { "Hyper-competition has been viewed as the continuous generation of new } \\
\text { forms of competitive advantage through neutralizing, destroying or rendering } \\
\text { competitors competitive advantages obsolete" (p. 647) }\end{array}$ \\
\hline $\begin{array}{l}\text { Harvey and } \\
\text { Novicevic (2001) }\end{array}$ & $\begin{array}{l}\text { "The global economy has created a new hypercompetitive landscape, one in } \\
\text { which events, competitors, environments, and industries change constantly } \\
\text { and unpredictably" (p. 449) } \\
\text { "By its very nature, the hypercompetitive landscape has become precipitously } \\
\text { more dynamic, intense, aggressive, and at the same time has become } \\
\text { deregulated, technology-intensive, and global in scope" (p. 449) }\end{array}$ \\
\hline $\begin{array}{l}\text { Harvey and } \\
\text { Novicevic (2002) }\end{array}$ & $\begin{array}{l}\text { "The enduring characteristics of hypercompetition are that (1) relative } \\
\text { competitive advantages are very time sensitive and therefore erode very } \\
\text { quickly, requiring that core competencies of global organizations be } \\
\text { rejuvenated constantly; (2) strategies must be formulated continuously to } \\
\text { seize competitive initiative resulting only in a temporary market advantage; } \\
\text { (3) there needs to be a modification in the conventional wisdom relative to }\end{array}$ \\
\hline
\end{tabular}


timeframes with attention being given to shorter and shorter life cycles; (4) the redefinition of industry boundaries, due to deregulation and the intrusion of nontraditional competitors entering the industry, will continue to occur; and (5) the dynamics of industries and competition are requiring management to address constant change and time as the common bases of global competition" (p. 490)

\begin{tabular}{|c|c|}
\hline $\begin{array}{l}\text { Hermelo and } \\
\text { Vassolo (2010) }\end{array}$ & $\begin{array}{l}\text { "Hypercompetition is the phenomenon that increases the speed and } \\
\text { aggressiveness of competition in the four arenas reducing the duration of the } \\
\text { launch, exploitation, and counterattack cycles" (p. 1459) }\end{array}$ \\
\hline Hinterhuber (2013) & $\begin{array}{l}\text { "Where this next round of competition is, and whether this move is indeed } \\
\text { profitable, is left unanswered" (p. 798) }\end{array}$ \\
\hline Hoisl et al. (2017) & $\begin{array}{l}\text { They obtain D'Aveni's (1994) definition: } \\
\text { "an environment characterized by intense and rapid competitive moves, in } \\
\text { which competitors must move quickly to build advantage and erode the } \\
\text { advantage of their rivals" (p. 1457) }\end{array}$ \\
\hline Kapur et al. (2003) & $\begin{array}{l}\text { "the horizontal, hypercompetitive world that is emerging will look radically } \\
\text { different and will require very different responses" (p. 36) }\end{array}$ \\
\hline $\begin{array}{l}\text { Khan and Azmi } \\
(2005)\end{array}$ & $\begin{array}{l}\text { "The hyper competitive global economy has created a new competitive } \\
\text { landscape-one in which events change constantly and unpredictably" (p. 42) }\end{array}$ \\
\hline $\begin{array}{l}\text { Kiessling et al. } \\
\text { (2004) }\end{array}$ & $\begin{array}{l}\text { "one in which events change constantly and unpredictably" (p. 94) } \\
\text { "the hypercompetitive marketplace is creating a new business climate that is } \\
\text { forcing organizations into adopting a new business model in order to sustain } \\
\text { viability within this highly technical arena" (p. 94-95) }\end{array}$ \\
\hline $\begin{array}{l}\text { Kim and Kogut } \\
\text { (1996) }\end{array}$ & $\begin{array}{l}\text { "Industries in which competitive advantages of innovations quickly erode are } \\
\text { commonly called 'Schumpeterian' or 'hypercompetitive" (p. 283) }\end{array}$ \\
\hline King (2013) & $\begin{array}{l}\text { Hypercompetition "require shorter product cycles and encounter more global } \\
\text { competition and greater uncertainty" (p. 22) }\end{array}$ \\
\hline Kriz et al. (2014) & $\begin{array}{l}\text { "Hypercompetition is demonstrated in industries characterised by turbulence, } \\
\text { volatility and competition, and is reflected in aspects such as fluctuation in } \\
\text { the demands of target markets" (p. 288) }\end{array}$ \\
\hline $\begin{array}{l}\text { Kulkarni and } \\
\text { Sivaraman (2019) }\end{array}$ & $\begin{array}{l}\text { "In a world which is fast changing and where competitive advantage } \\
\text { evaporates in short periods, firms cannot rely and spend months on crafting a } \\
\text { single long-term strategy; they need to be agile and think of many new } \\
\text { strategic initiatives to remain competitive" (p. 1) }\end{array}$ \\
\hline Lahiri et al. (2008) & $\begin{array}{l}\text { "Hypercompetition is the extreme rivalry whereby competing firms position } \\
\text { themselves aggressively against one another, and seek to disrupt the } \\
\text { competitive advantages of industry leaders" (p. 314) }\end{array}$ \\
\hline Lee et al. (2010) & $\begin{array}{l}\text { "A hypercompetitive industry is 'characterized by intense and rapid } \\
\text { competitive moves, in which competitors must move quickly to build } \\
\text { advantage and erode the advantage of their rivals" (p. 1431) }\end{array}$ \\
\hline $\begin{array}{l}\text { Li and Chuang } \\
\text { (2001) }\end{array}$ & $\begin{array}{l}\text { "the hypercompetitive rivalry perspective embraces the idea that firms' } \\
\text { competitive advantages will be short-lived as competitors' aggressive }\end{array}$ \\
\hline
\end{tabular}


strategic actions frequently disrupt causal linkages between strategic conduct and firm performance" (p. 331)

\begin{tabular}{l|l}
\hline Liao et al. (2010) & $\begin{array}{l}\text { "Fast changing internet-based environment" (p. 263) } \\
\text { "most challenging and competitive environments for entrepreneurs" (p. 264) } \\
\text { "The dynamic, disequilibrium nature of hypercompetitive industries forces } \\
\text { firms competing within them to launch strategic actions continuously as they } \\
\text { pursue a stream of temporary competitive advantages" (p. 264) }\end{array}$ \\
\hline $\begin{array}{l}\text { Lindskov et al. } \\
\text { (2020) }\end{array}$ & $\begin{array}{l}\text { "hypercompetition', a state of intense industry rivalry, making it impossible } \\
\text { to sustain competitive advantages" (p. 1) }\end{array}$ \\
\hline Mahto et al. (2018) & $\begin{array}{l}\text { "Hypercompetition represents environments where sustainable competitive } \\
\text { advantages become rare and decline with duration" (p. 231) }\end{array}$ \\
\hline Makadok (1998) & $\begin{array}{l}\text { "a fast-paced global marketplace in which it is increasingly difficult to } \\
\text { sustain competitive advantages for any length of time" (p. 684) }\end{array}$ \\
\hline $\begin{array}{l}\text { McNamara et al. } \\
\text { "greater levels of competition" (p. 158) }\end{array}$ & $\begin{array}{l}\text { "Hypercompetition increases the frequency of decision making and } \\
\text { consequently decreases the stability of markets and business performance } \\
\text { over time. Unless there is a rather substantial improvement in the decision- } \\
\text { making capabilities of businesses, as markets become more hypercompetitive, } \\
\text { there will be less stability in performance across the population over time" (p. } \\
\text { 264) }\end{array}$
\end{tabular}

"A hypercompetitive shift in markets leads to greater competitive pressures that, in turn, should increase the rate of decay of abnormal business returns" (p. 264) Nath and Newell "rapidly changing competitive rules due to changing consumer preferences, (1998) erosion of traditional barriers to entry and development of new entry barriers, and inability to maintain a sustainable competitive advantage for any length of time due to easy imitability" (p. 43)

Ngamkroeckjoti $\quad$ “... has defined the nature of hypercompetition as a state of intense and Johri (2003) environmental change, in which flexible and innovative players enter the markets rapidly while eroding the advantages of the established players" ( $\mathrm{p}$. 362)

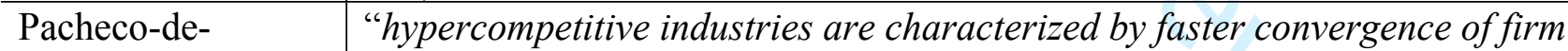
Almeida (2010) profits to the industry mean" (p. 1502) Palmer et al. (2001)

"This argument portrays the business environment as having moved away from being a relatively stable set of conditions to one characterized by fast changing, highly competitive conditions. Labels such as discontinuous, postbureaucratic, and chaotic have been used to describe the current period, which for some is associated with the emergence of a postmodern organizational paradigm" (p. 191)

Panigrahi (2019) "in the global market characterized by an oligopolistic market structure with sticky output price phenomenon" (p. 1) 
Parayre et al. $\quad$ "Hypercompetition thus differs from normal competition, as it involves a (2001) departure from the usual type of competitive equilibrium" (p. 281)

Pavlak and Hurry “Today's contemporary business environment is very volatile" (p. 362) (2020)

\begin{tabular}{l|l}
\hline Priporas (2019) & ' \\
\hline Richardson (1996) & ' $C(~$
\end{tabular}
"globalized, dynamic, uncertain and vulnerable environment" (p. 998); 
filter new information and to apply such information quickly in order to provide effective directions to the people they manage" (p. 284)

\begin{tabular}{l|l}
\hline Weber (1998) & $\begin{array}{l}\text { "Today's more open markets and the related proliferation of competitors } \\
\text { from around the globe have shortened technology and product life cycles and } \\
\text { intensified pressures to provide more customer responsive and value based } \\
\text { market offerings" (p. 548) }\end{array}$ \\
\hline $\begin{array}{l}\text { Wiggins and Ruefli } \\
(2005)\end{array}$ & $\begin{array}{l}\text { " an environment characterized by intense and rapid competitive moves, in } \\
\text { which competitors must move quickly to build advantage and erode the } \\
\text { advantage of their rivals" (D'Aveni, 1994: 217-218)" (p. 888) }\end{array}$ \\
\hline
\end{tabular}

Young et al. (1996) "market environments characterized by extremely vigorous competitive action, in which sustainability of competitive ad-vantage depends on the speed of action and the extent of competitive rivalry" (p. 243)

Zohar and Morgan "A way to explore new insights" (p. 462) (1996) 